\title{
Article \\ Concrete with Partial Substitution of Waste Glass and Recycled Concrete Aggregate
}

\author{
Jawad Ahmad 1,*(D), Rebeca Martínez-García ${ }^{2}{ }^{\circ}$, Jesús de-Prado-Gil ${ }^{2}$, Kashif Irshad ${ }^{3,4}(\mathbb{D}$, \\ Mohammed A. El-Shorbagy ${ }^{5}{ }^{(0)}$, Roman Fediuk ${ }^{6}\left(\mathbb{B}\right.$ and Nikolai Ivanovich Vatin ${ }^{7}{ }^{(0)}$
}

check for

updates

Citation: Ahmad, J.; Martínez-García,

R.; de-Prado-Gil, J.; Irshad, K.;

El-Shorbagy, M.A.; Fediuk, R.;

Vatin, N.I. Concrete with Partial

Substitution of Waste Glass and

Recycled Concrete Aggregate.

Materials 2022, 15, 430. https://

doi.org/10.3390/ma15020430

Academic Editors: Alessandro P.

Fantilli and Miguel Ángel Sanjuán

Received: 7 December 2021

Accepted: 4 January 2022

Published: 7 January 2022

Publisher's Note: MDPI stays neutral with regard to jurisdictional claims in published maps and institutional affiliations.

Copyright: (c) 2022 by the authors. Licensee MDPI, Basel, Switzerland. This article is an open access article distributed under the terms and conditions of the Creative Commons Attribution (CC BY) license (https:// creativecommons.org/licenses/by/ $4.0 /)$.
1 Department of Civil Engineering, Military College of Engineering (Nust), Risalpur 24080, Pakistan

2 Department of Mining Technology, Topography, and Structures, University of León, Campus de Vegazana s/n, 24071 León, Spain; rmartg@unileon.es (R.M.-G.); jesusdepradogil@gmail.com (J.d.-P.-G.)

3 Interdisciplinary Research Center for Renewable Energy and Power Systems (IRC-REPS), King Fahd University of Petroleum \& Minerals, Dhahran 31261, Saudi Arabia; Kashif.irshad@kfupm.edu.sa

4 K.A. CARE Energy Research \& Innovation Center at Dhahran, Dhahran 31261, Saudi Arabia

5 Department of Mathematics, College of Science and Humanities in Al-Kharj, Prince Sattam bin Abdulaziz University, Al-Kharj 11942, Saudi Arabia; mohammed_shorbagy@yahoo.com

6 Polytechnic Institute, Far Eastern Federal University, 690922 Vladivostok, Russia; fedyuk.rs@dvfu.ru

7 Peter the Great Saint Petersburg Polytechnic University, 195251 Saint Petersburg, Russia; vatin@mail.ru

* Correspondence: jawadcivil13@scetwah.edu.pk

\begin{abstract}
The current practice of concrete is thought to be unsuitable because it consumes large amounts of cement, sand, and aggregate, which causes depletion of natural resources. In this study, a step towards sustainable concrete was made by utilizing recycled concrete aggregate (RCA) as a coarse aggregate. However, researchers show that RCA causes a decrease in the performance of concrete due to porous nature. In this study, waste glass (WG) was used as a filler material that filled the voids between RCA to offset its negative impact on concrete performance. The substitution ratio of WG was 10,20, or 30\% by weight of cement, and RCA was 20,40 , and $60 \%$ by weight of coarse aggregate. The slump cone test was used to assess the fresh property, while compressive, split tensile, and punching strength were used to assess the mechanical performance. Test results indicated that the workability of concrete decreased with substitution of WG and RCA while mechanical performance improved up to a certain limit and then decreased due to lack of workability. Furthermore, a statical tool response surface methodology was used to predict various strength properties and optimization of RCA and WG.
\end{abstract}

Keywords: sustainable concrete; compressive strength; split tensile strength; waste glass

\section{Introduction}

Environmental groups are pushing for the use of RCA and solid wastes such as slag, fly ash, and silica fume in construction projects. The global demand for aggregates for construction is expected to reach 47 billion metric tons per year in 2023 [1]. The solution is to reuse or include solid waste byproducts including fly ash, silica fume, bottom ash, slag, and glass waste into the concrete manufacturing process [1-4]. These concrete advances diminish the negative impacts of the concrete industry in affordable and natural issues by providing low costs, high strength properties, and ecological amicability [5-7]. Currently, the usage of reused aggregate concrete, which is made from waste concrete brought in from building sites and demolition, is being promoted to help alleviate the global scarcity of regular aggregate. Furthermore, by recycling waste concrete aggregate, concerns associated with removing the massive volume of waste concrete generated on building sites and demolition activities might be reduced up to certain extent [1].

By volume, RA is made up of 60-70 percent natural aggregates and 30-40 percent aged cement mortar. Parent concrete qualities, workability, mix percentage, and other factors influence the compressive strength and other properties of recyled aggregate concrete [8-10]. 
When compared to concrete with natural aggregates, the mechanical and durability performance of RCA is worse. By using fractional substitution of pozzolanic components and mineral admixtures, RCA's inferior performance might be improved. By filling the RCA porosity microstructure and lowering RCA permeability, these compounds and admixtures improve durability $[11,12]$. Using RCA as coarse aggregate in concrete has a number of environmental advantages. However, because of its porous nature, RCA has been shown to reduce the mechanical performance of concrete. As a result, some filler material must be added to RCA, filling the gaps and resulting in a more compact mass. There are various filler materials, such as fly ash [13], silica fume [14,15], waste glass [16], wheat straw ash [4], marble waste [17], bentonite clay [18], as well as GGBS [19]. In this study, waste glass was used as the filler material.

As of 2005, the overall worldwide waste glass manufacture valuation was $130 \mathrm{Mt}$, in which the European Union, China, and the USA manufactured roughly $33 \mathrm{Mt}, 32 \mathrm{Mt}$, and $20 \mathrm{Mt}$, respectively [20]. As glass is nonrecyclable, glass-dumping in a landfill creates an environmental problem. Because of these reasons, the use of waste glass and waste marble materials from industries came into the picture to reduce the waste from manufacturing units and decrease the scarcity of basic natural resources.

On the other hand, the yearly worldwide cement manufacture has moved 2.8 billion tons and is supposed to rise to some four billion tons each year. Cement production is challenging because of expense rises in energy resources, decreasing $\mathrm{CO}_{2}$ releases, and depletion of natural resources $[9,21,22]$. Several industrial byproducts have been used effectively in concrete, including silica fume, ground granulated blast furnace slag, and fly ash $[23,24]$. The practice of waste glass to change cement could decrease the cost of concrete and the depletion of cement, thereby precisely decreasing the $\mathrm{CO}_{2}$ production associated with cement manufacture.

Glass exhibits pozzolanic behavior if the particle size is smaller than $75 \mu \mathrm{m}$. Silica in glass interacts with calcium hydrates $\left(\mathrm{Ca}(\mathrm{OH})_{2}\right)$ to form calcium silicate hydrate $(\mathrm{CSH})$ [25]. Glass has also been found to exhibit pozzolanic properties when the particle size is smaller than $150 \mu \mathrm{m}$. However, the pozzolanic behaviors increase as particle size decreases, i.e., $35 \mu \mathrm{m}$ shows better results than $150 \mu \mathrm{m}$ [26,27].

It has been concluded that slump is decreased with the addition of waste glass. However, compressive and flexure strength increases up to $20 \%$ replacement and then decreases gradually [28]. It has been concluded that the flexure strength of the beam is increased with the addition of waste glass [29]. It has been shown that the compression strength level was $13.64 \%$ at seven days and $2.18 \%$ at 28 days at $20 \%$ replacement of glass [30]. Finely ground glass powder has been found to exhibit pozzolanic properties which increase the strength of concrete. [31,32]. The results show that compressive strength is about $12 \%, 2.5 \%$, and $1.5 \%$ higher than that of reference concrete with substitution of waste glass. However, a high dosage of waste glass may negatively impact the strength property of concrete due to dilution effects. Excessive silica without the necessary calcium $(\mathrm{CH})$ forms weak pockets (the alkali-silica reaction), and as a result, strength starts to decrease [25]. Therefore, it is essential to choose the optimum dose of waste glass for the better mechanical performance of concrete.

The literature shows that RCA decreases the performance of concrete due to its porous nature, and waste glass has the credibility to be used as a filler material. Therefore, waste glass was used as a filler material that filled the voids of RCA and offset its negative impact on the mechanical performance of concrete. Furthermore, a response surface methodology was used to optimize RCA and WG. The overall study demonstrates that the combined substitution of WG and RCA successfully improved mechanical performance considerably. 


\section{Materials and Methods}

\subsection{Materials}

\subsubsection{Cement}

As per ASTM C150 Type-1, Ordinary Portland cement (Bestway cement Islamabad Pakistan) was used throughout the experimental work to prepare the mix for all batches. The physical and chemical aspects of cement used in this study are shown in Table 1.

Table 1. Properties of Ordinary Portland Cement (OPC).

\begin{tabular}{cccc}
\hline Chemical Name & Percentage (\%) & Physical Name & Results \\
\hline $\mathrm{CaO}$ & 63.7 & Size & Less than $75 \mu \mathrm{m}$ \\
$\mathrm{SiO}_{2}$ & 22.9 & Fineness & $97 \%$ \\
$\mathrm{Al}_{2} \mathrm{O}_{3}$ & 4.2 & Normal Consistency & $29 \%$ \\
$\mathrm{Fe}_{2} \mathrm{O}_{3}$ & 3.5 & Initial Setting Time & $38 \mathrm{~min}$ \\
$\mathrm{MgO}$ & 3.0 & Final Setting Time & $430 \mathrm{~min}$ \\
$\mathrm{SO}_{3}$ & 1.4 & Specific surface & $320 \mathrm{~m}^{2} / \mathrm{kg}$ \\
$\mathrm{K}_{2} \mathrm{O}$ & 0.5 & Soundness & $1.60 \%$ \\
$\mathrm{Na}_{2} \mathrm{O}$ & 0.8 & 28 days compressive Strength & $42 \mathrm{MPa}$ \\
\hline
\end{tabular}

\subsubsection{Waste Glass}

Waste glass was procured from a local shop Kohat Pakistan. The waste glass used in the research was transparent soda-lime glass. The waste glass was ground using ball mill grinding equipment at the PCSIR lab in Peshawar, Pakistan, to reach a particle size equivalent to or less than that of the cement particle size. The physical and chemical aspects of waste glass used in this study are shown in Table 2, while X-ray diffraction (XRD) is given in Figure 1. At 26, 38, and 50 degrees, many amorphous peaks of quartz (Q) in the XRD analysis of WG showed the major amorphous nature of WG. The chemical composition of WG showed that the material may have had pozzolanic potential, which can be attributed to the accumulative chemical composition of $\mathrm{SiO}_{2}, \mathrm{Al}_{2} \mathrm{O}_{3}$, and $\mathrm{Fe}_{2} \mathrm{O}_{3}$ exceeding $70 \%$.

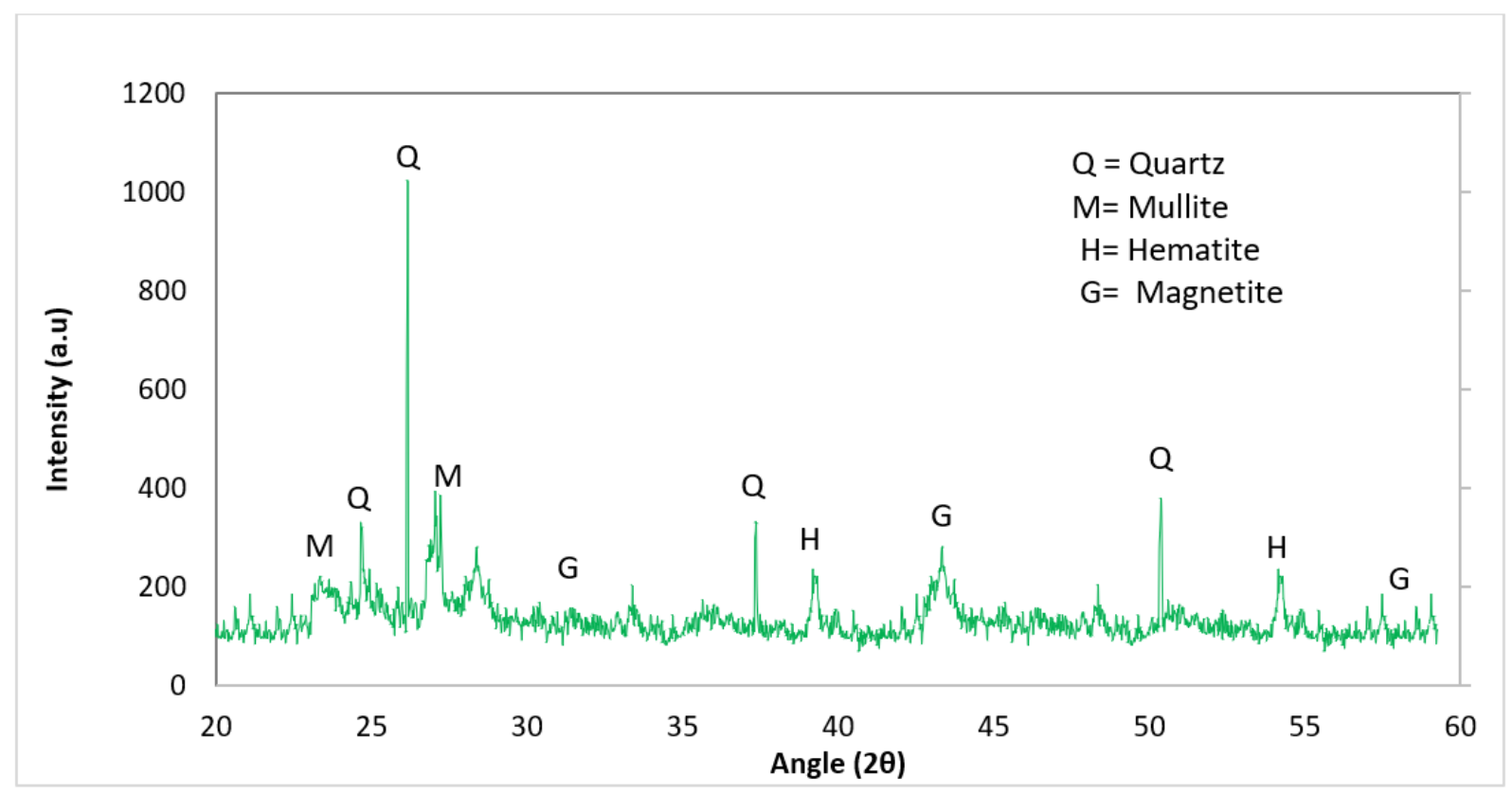

Figure 1. XRD result of waste glass. 
Table 2. Properties of waste glass.

\begin{tabular}{cccccc}
\hline Chemical Name & Percentage (\%) & Property Name & Value & Mineralogy & Quartz \\
\hline $\mathrm{CaO}$ & 60.7 & Size & Less than $75 \mu \mathrm{m}$ & Loss of ignition $(\%)$ & 4.8 \\
$\mathrm{SiO}_{2}$ & 24.9 & Fineness & $98 \%$ & Water content $(\%)$ & Clay $(\%)$ \\
$\mathrm{Al}_{2} \mathrm{O}_{3}$ & 4.7 & Specific surface & $342 \mathrm{~m}^{2} / \mathrm{kg}$ & TOC $(\mathrm{mg} / \mathrm{kg})$ & 6.1 \\
$\mathrm{Fe}_{2} \mathrm{O}_{3}$ & 2.0 & Specific gravity & 3.1 & 0.1 & 64.9 \\
$\mathrm{MgO}_{\mathrm{SO}}$ & 1.9 & Absorption & 0.01 & Hydrocarbons $(\mathrm{mg} / \mathrm{kg})$ & 75.13 \\
$\mathrm{SO}_{3}$ & 2.5 & & & Sulphates $(\%)$ & 3.08 \\
$\mathrm{~K}_{2} \mathrm{O}$ & 0.2 & & & $\mathrm{HHV}(\mathrm{kJ} / \mathrm{kg})$ & 170.5 \\
$\mathrm{Na}_{2} \mathrm{O}$ & 1.1 & & & PCB $(\mathrm{mg} / \mathrm{kg})$ & 0.28 \\
\hline
\end{tabular}

\subsubsection{Aggregates}

In saturated surface dry conditions, natural river sand was employed as a fine aggregate in all batches. For all batches, normal weight coarse aggregate with a maximum size of $25 \mathrm{~mm}$ was employed in saturated surface dry conditions. RCA of $25 \mathrm{~mm}$ maximum size was obtained by crushing waste concrete. A variety of tests were carried out on the aggregates to assess its physical properties, and the results are given in Table 3. For aggregate gradation (sieve analysis), an ASTM standard (ASTM33/C33M-13) was utilized, as indicated in Figure 2.
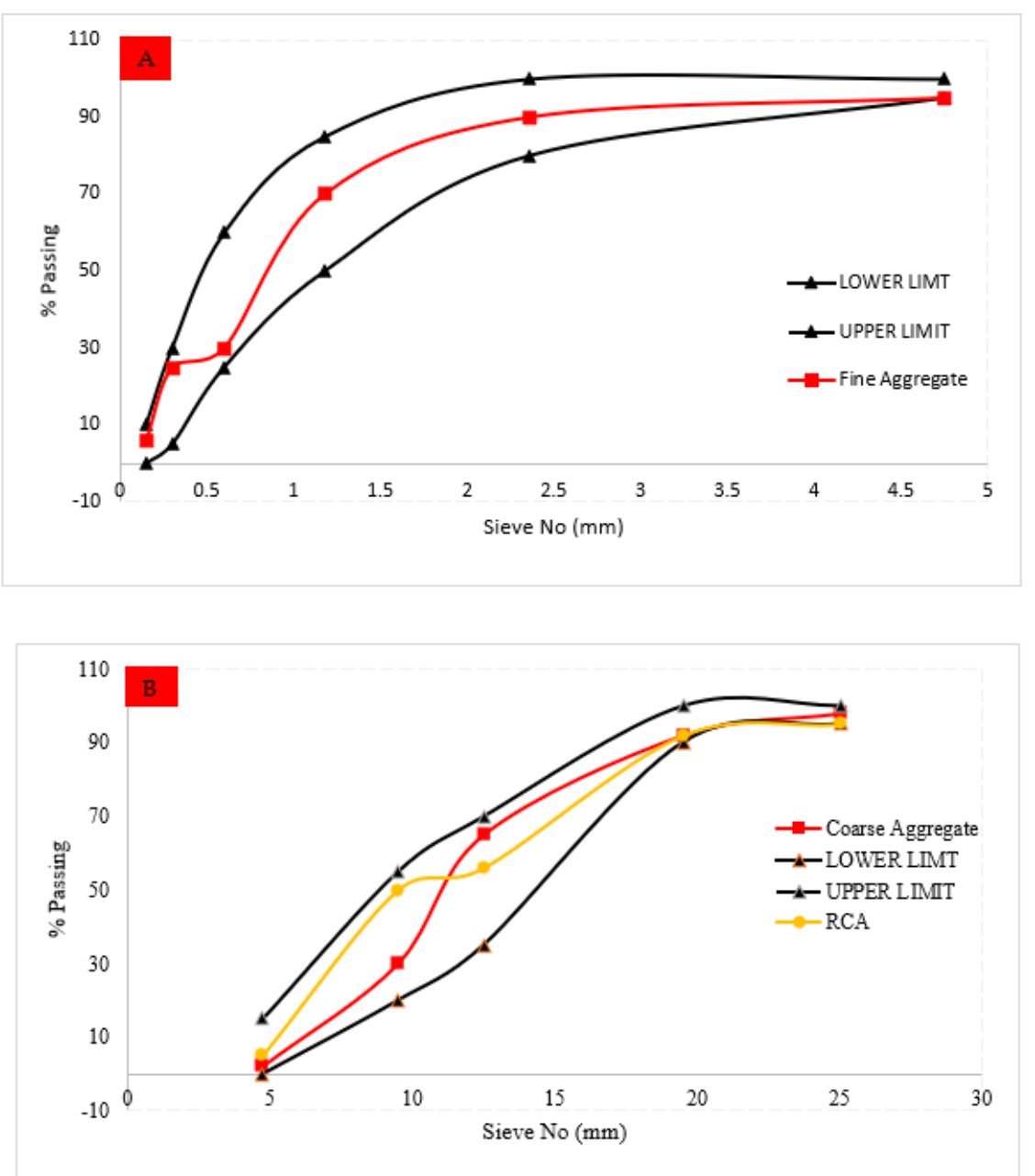

Figure 2. Particle size distribution curve of (A) fine aggregate and (B) coarse aggregate. 
Table 3. Fine and coarse aggregate properties.

\begin{tabular}{cccc}
\hline Property & Fine Aggregate & Coarse Aggregate & RCA \\
\hline Particle Size & 4.75 to $0.075 \mathrm{~mm}$ & 25 to $4.75 \mathrm{~mm}$ & 25 to $4.75 \mathrm{~mm}$ \\
Fineness Modulus & 2.53 & 3.8 & 2.2 \\
Absorption Capacity & $4.26 \%$ & $2.28 \%$ & $3.3 \%$ \\
Moisture Content & $2.8 \%$ & $0.55 \%$ & $0.75 \%$ \\
Specific Gravity & 2.91 & 2.45 & 2.35 \\
\hline
\end{tabular}

\subsection{Response Surface Methodology (RSM)}

RSM is a mathematical and statistical combined technique to estimate relations between a set of input independent variables and output variables [33]. Experimental results are required, and then based on these experimental results, a numerical model is developed [34]. Additionally, RSM is additionally used as an experimental design technique for the modeling and analysis of difficulties in which a response of interest is assessed by several variables $[33,35]$. This method is generally used when several input variables affect the output variable. Equation (1) (first-order model) was utilized to calculate the quantity of the experimentation [36].

$$
Y=\beta 0+\sum_{i=1}^{k} \beta \mathrm{i} X_{i}+\varepsilon
$$

Equation (2) (second-order model) illustrated the model utilized to estimate the responses and define the relationship between the independent variables.

$$
Y=\beta 0+\sum_{i=1}^{k} \beta \mathrm{ii} X_{i}+\sum_{i=1}^{k} \beta \mathrm{i} X_{i}^{2}+\sum \sum_{i \leq 1} \beta \mathrm{ij} X_{i} X_{j}+\varepsilon
$$

where:

$\mathrm{Y}=$ response function (for this study it is the CS),

$\mathrm{B} 0=$ constant coefficient

$\mathrm{Bi}, \mathrm{Bii}$, and $\mathrm{Bij}=$ factor of the linear, quadratic, and interactive expressions, respectively [4].

In this study, the quadratic model was used for the prediction.

\subsection{Test and Sample Preparation Method}

The flow of concrete was determined as per ASTM [37]. The compressive strength was measured using a standard cylinder $(150 \times 300 \mathrm{~mm})$ in accordance with ASTM standards [38]. Similar cylinders of standard dimensions $(150 \times 300 \mathrm{~mm})$ were cast and tested for split tensile strength in accordance with ASTM standards [39]. Punching shear was performed on a concrete slab specimen of $500 \times 500 \mathrm{~mm}$. For this test, a special kind of assembly was made that represented the punching mechanism in the slabs in concrete structures, as shown in Figure 3. To find out the punching shear strength of the concrete slabs, the slab specimens were removed from the curing procedure and were left to dry in the open air for two hours. Then, a steel baseplate was placed in the compressive testing machine. After that, the slab specimen was placed over the baseplate, and it was made sure that the center of the slab specimen lay at the center of the baseplate. Then, the central point was marked on the top surface of the slab, and the punching rod was placed on the central marked point, as shown in Figure 3. The loading was started by turning the loading switch on and waiting until the rod punched in the slab. The maximum resistive punching load of the slab specimen was noted down. 


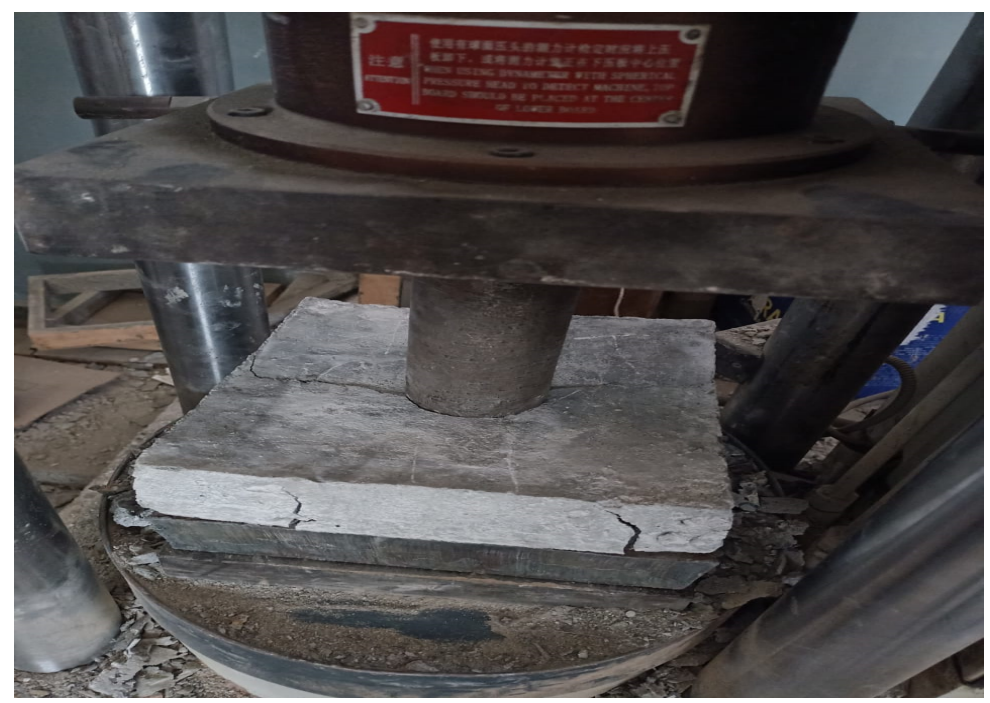

Figure 3. Punching strength setup.

For each test, three specimens were tested at 7, 28, and 56 days, and the mean value of the specimens was considered the strength of the experiment. The ASTM C-31 [40] method was followed to prepare the specimens, and compaction was done manually by Roding in three layers with 25 blows to each layer. Before the mixing process started, the required quantity of concrete ingredients was weighed by the weighing system. The mixer rate was kept constant at $30 \mathrm{rev} / \mathrm{min}$ for the blending of ingredients. Initially, coarse and RCA were put into the drum and then sand. Each ingredient was dry-blended with the essential amount of OPC and WG, water was inserted over time, and blending was performed for around 10 minutes for all batches. A total of fifteen mixed proportions were prepared, i.e., one control mix, six mixes individually with varying percentages of WG and RCA, and eight with combined substitutions of WG and RCA which were determined from statistical analysis. A total of 192 standard sizes were cast and tested as per the specified period of curing. Table 4 depicts the mixed proportion of control and individual mixes.

Table 4. Quantification of materials per cubic meter.

\begin{tabular}{|c|c|c|c|c|c|c|c|}
\hline Mix ID & Cement (kg) & $\begin{array}{c}\text { Fine Aggregate } \\
(\mathbf{k g})\end{array}$ & $\begin{array}{c}\text { Coarse Aggregate } \\
(\mathrm{kg})\end{array}$ & $\begin{array}{l}\text { WG } \\
(\mathrm{kg})\end{array}$ & $\begin{array}{l}\text { RCA } \\
(\mathbf{k g})\end{array}$ & $\begin{array}{l}\text { Water } \\
(\mathrm{kg})\end{array}$ & $\begin{array}{l}\text { Admixture } \\
(\mathrm{kg})\end{array}$ \\
\hline Control & 385 & 550 & 1150 & - & - & 180 & 4.25 \\
\hline W-10-R-0 & 346.5 & 550 & 1150 & 38.5 & - & 180 & 4.25 \\
\hline W-20-R-0 & 308 & 550 & 1150 & 77 & - & 180 & 4.25 \\
\hline W-30-R-0 & 265.5 & 550 & 1150 & 115.5 & - & 180 & 4.25 \\
\hline W-0-R-20 & 385 & 550 & 920 & - & 230 & 180 & 4.25 \\
\hline W-0-R-40 & 385 & 550 & 690 & - & 460 & 180 & 4.25 \\
\hline W-0-R-60 & 385 & 550 & 460 & - & 690 & 180 & 4.25 \\
\hline
\end{tabular}

\section{Results and Discussion}

\subsection{Workability}

Workability can be defined as the ease of concrete mixing, transportation, placing, and compacting. Workability directly affects the mechanical performance of concrete. More workable concrete results more compact dense concrete [41]. Figure 4 depicts the slump flow of concrete with different doses of WG. RCA slump value decreased as the percentage of waste glass increased compared to that in the control mix. 


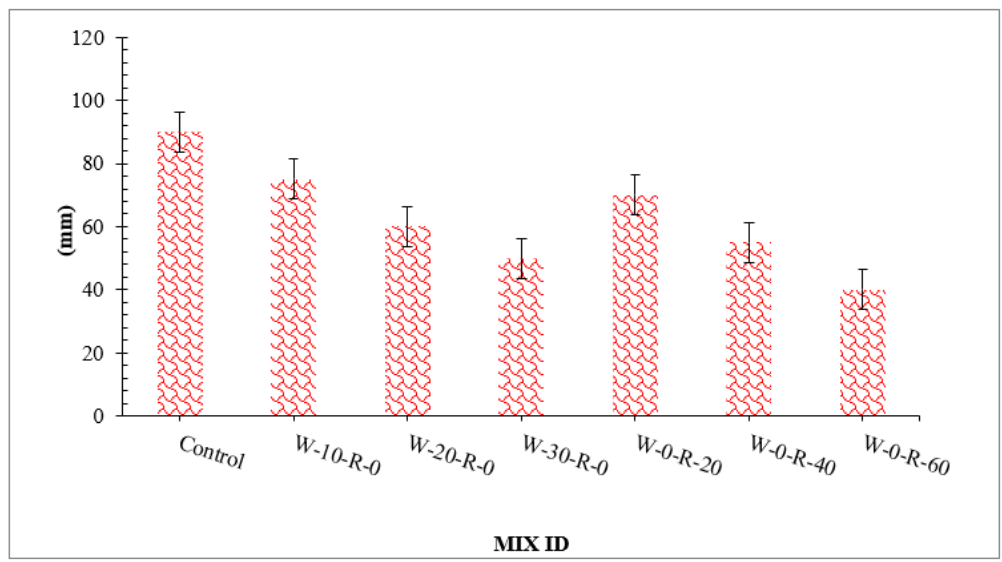

Figure 4. Slump test result.

The maximum slump was attained at $0 \%$ replacement of waste glass, and the minimum slump was achieved at $30 \%$ substitution of waste glass. Research also shows that the workability of concrete reduces with the replacement of waste glass [42]. The decrease in workability was because of a larger surface area of waste glass, as shown in Table 2, which required more cement paste to coat them, and hence less cement paste was available for lubrication. Although some studies show that waste glass does not absorb water from the concrete mix, more water is available for lubrication, resulting in more workable concrete [43]. RCA decreased the workability of concrete by absorbing more water from the concrete due to its porous nature and as a result, there was no free water available for lubrication. Research also reports that the workability of concrete decreases with the substitution of RCA due to rough texture, which enhances internal friction between concrete ingredients [42].

\subsection{Compressive Strength of Concrete}

Figure 5 shows compressive strength with differing dosages of WG and RCA. Based on work results, compressive strength of concrete improved with substitution of waste glass up $20 \%$ and then decreased due to lack of workability.

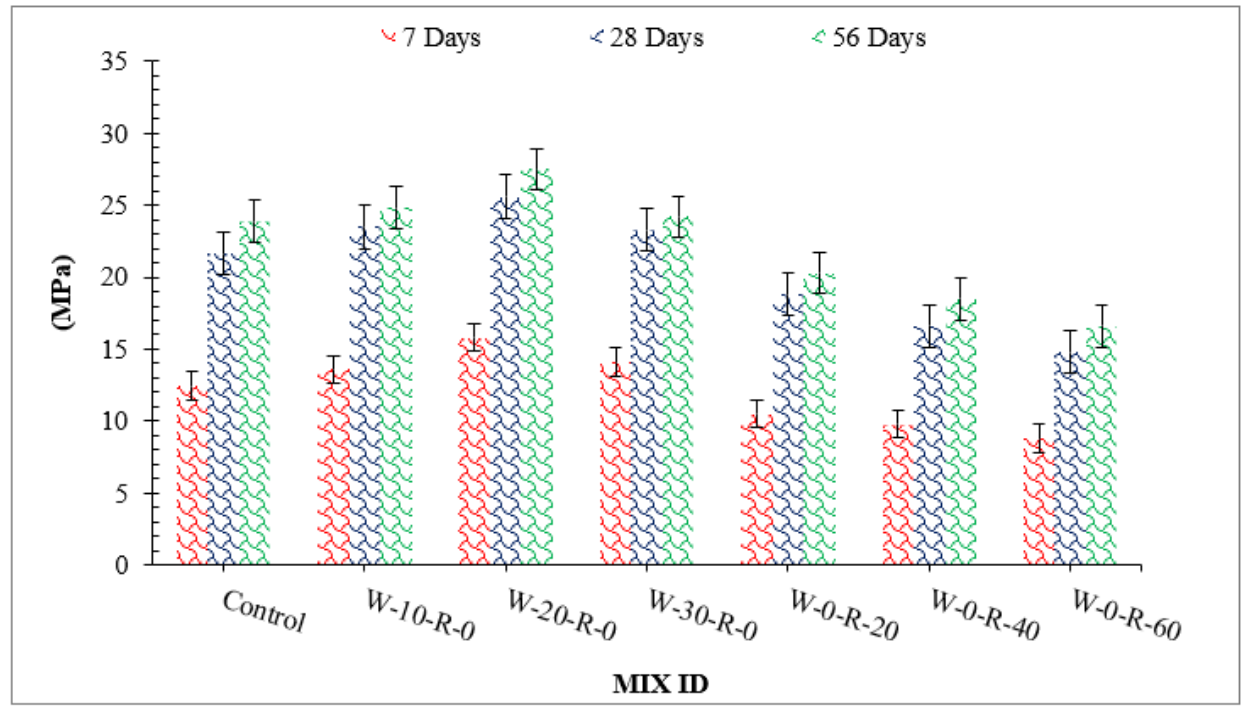

Figure 5. Compressive strength.

The pozzolanic reaction of waste glass is responsible for the increased compressive strength. Silica present in waste glass reacts with $\mathrm{CH}$ (formed during hydration of cement) and converts it into CSH gel, which provides additional binding property. As a result, 
strength increases. It can also be observed that improvement in compressive strength at an early stage (seven days) was not significant with the substitution of waste glass, as the pozzolanic reaction proceeds slowly [44]. However, 28 and 56 days of curing considerably improved compressive strength. It is also mentioned that improved compressive strength is due to micro filling of WG, which gives denser concrete [4]. However, a decrease in compressive strength was observed beyond $20 \%$ replacement of waste glass owing to a lack of workability, resulting in more voids in hardened concrete. Additionally, a study shows that a higher dose of waste glass (30\%) results in less compressive strength due to the dilution effect, which causes an alkali-silica reaction. The amount of calcium hydrates $(\mathrm{CH})$ is consumed by the chemical reaction with silica present in waste glass which gives secondary cementitious material (CSH gel), but at a higher dose of waste glass, might be caused by an alkali-silica reaction due to excessive unreactive silica. As for RCA, compressive strength decreased with substitution of RCA as compared to that of control, with minimum compressive strength at $60 \%$ substitution of RCA. The physical nature of RCA causes it to absorb more water, resulting in porous concrete with lower compressive strength. The compressive strength of recycled aggregate concrete has also been observed to be reduced due to unreactive cement [45]. No free water is available for the hydration process since RCA absorbs water from concrete. In addition, lack of workability tends to cause more voids, resulting in lower compressive strength.

A relative analysis of compressive strength concerning 28 days of control concrete is shown in Figure 6. Compressive strength at seven days of curing was 31\% and 52\% lower than that of reference concrete ( 28 days control concrete) at $20 \%$ substitution of waste glass and $20 \%$ substitution of RCA, respectively. Compressive strength at $20 \%$ substitution of waste glass was $19 \%$ higher than that in reference concrete, and at $20 \%$ substitution of RCA was $14 \%$ lower than that of reference concrete at 28 days of curing. Compressive strength at 56 days of curing was $27 \%$ higher than that of reference concrete at $20 \%$ substitution of waste glass and only $7.0 \%$ lower than that of reference concrete at $30 \%$ substitution of RCA, respectively.

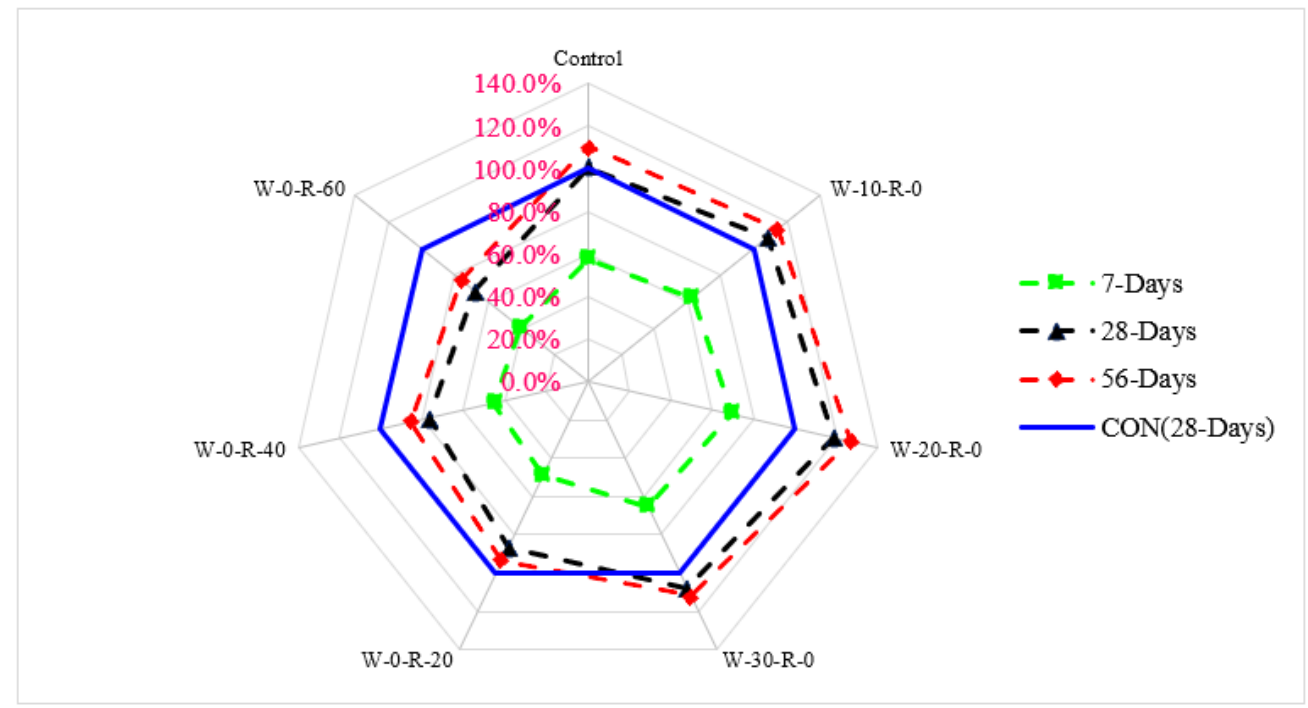

Figure 6. Relative compressive strength. 
Response surface and contour plot for compressive strength after 28 days of curing are shown in Figures 7 and 8, respectively. It can be observed from the contour plot that RCA decreased compressive strength while WG improved compressive strength. However, concrete made with $20 \% \mathrm{WG}$ and 30\% RCA showed compressive strength $(20.5 \mathrm{MPa})$ approximately equal to the compressive strength of control $(21.65 \mathrm{MPa})$, as shown in Figure 9. Furthermore, concrete with 15\% RCA and 20\% WG showed a compressive strength of $23 \mathrm{MPa}$, which was $7.0 \%$ higher than the compressive strength of control. Similar doses (15\% RCA and 20\% WG) were also cast and tested in the laboratory. It can be observed that experimental compressive and predicted compressive strength from the contour plot were approximately equal, which validated the predicted results. Therefore, the overall discussion suggests that RCA up to $40 \%$ with a combination of $20 \%$ WG could be safely used in cement concrete production without adverse effects on compressive strength.

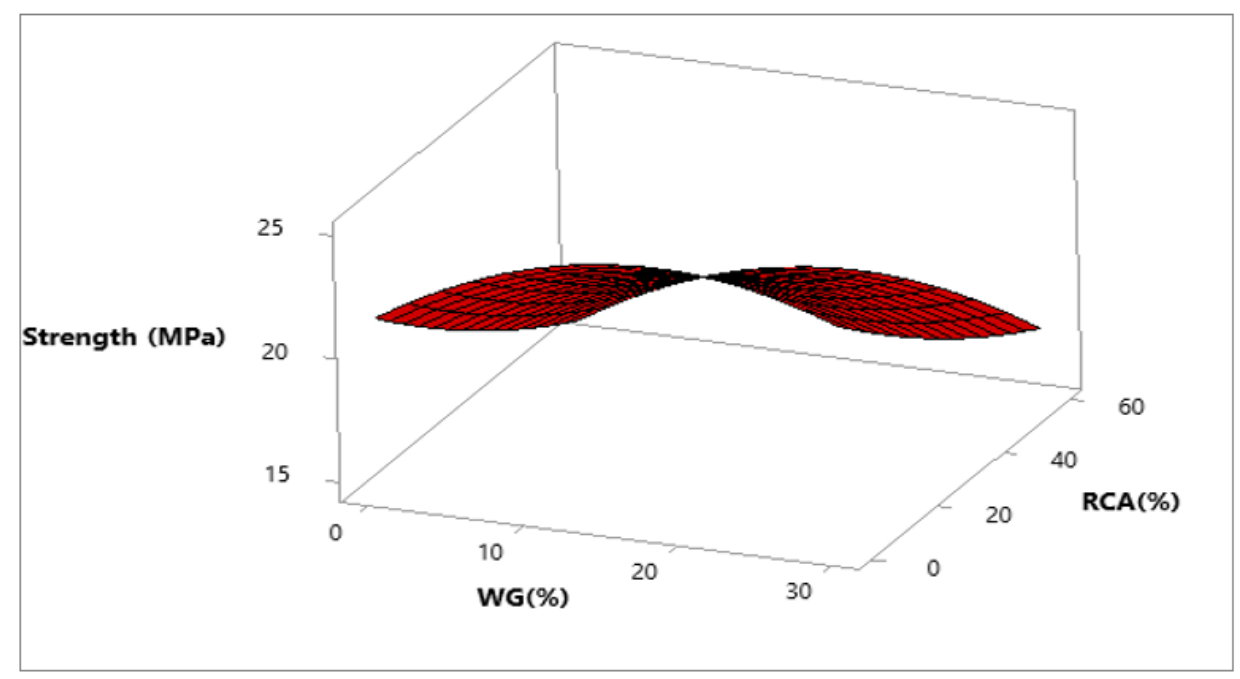

Figure 7. Three-dimensional response surface of compressive strength.

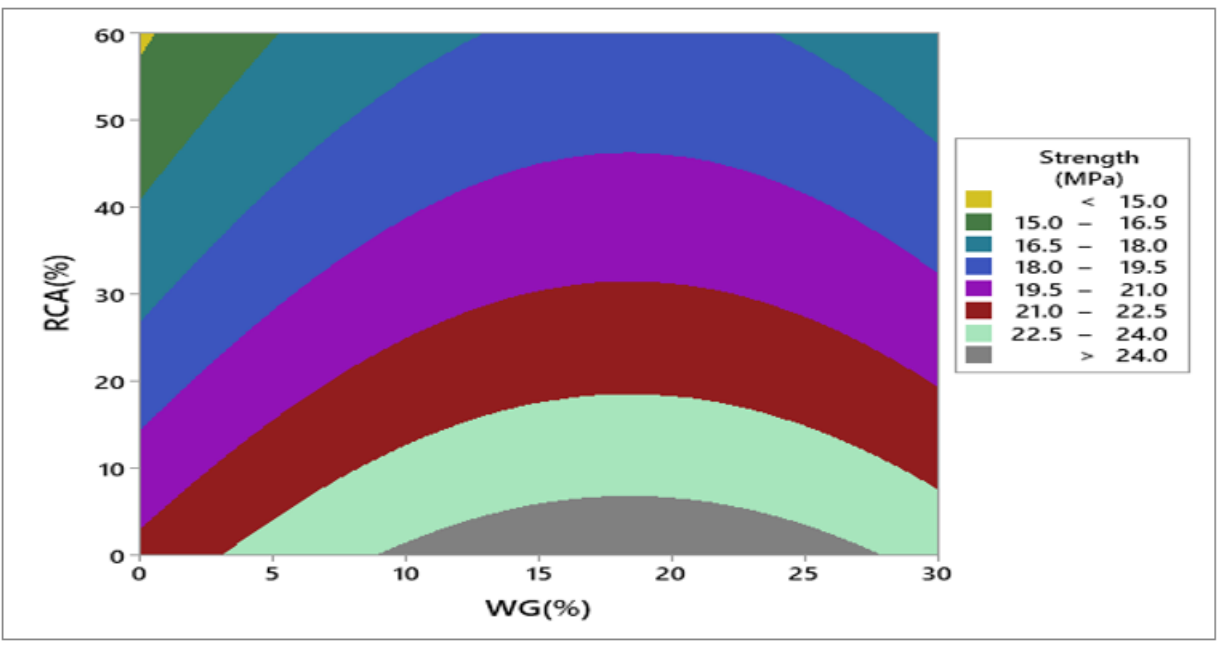

Figure 8. Contour plot of compressive strength. 


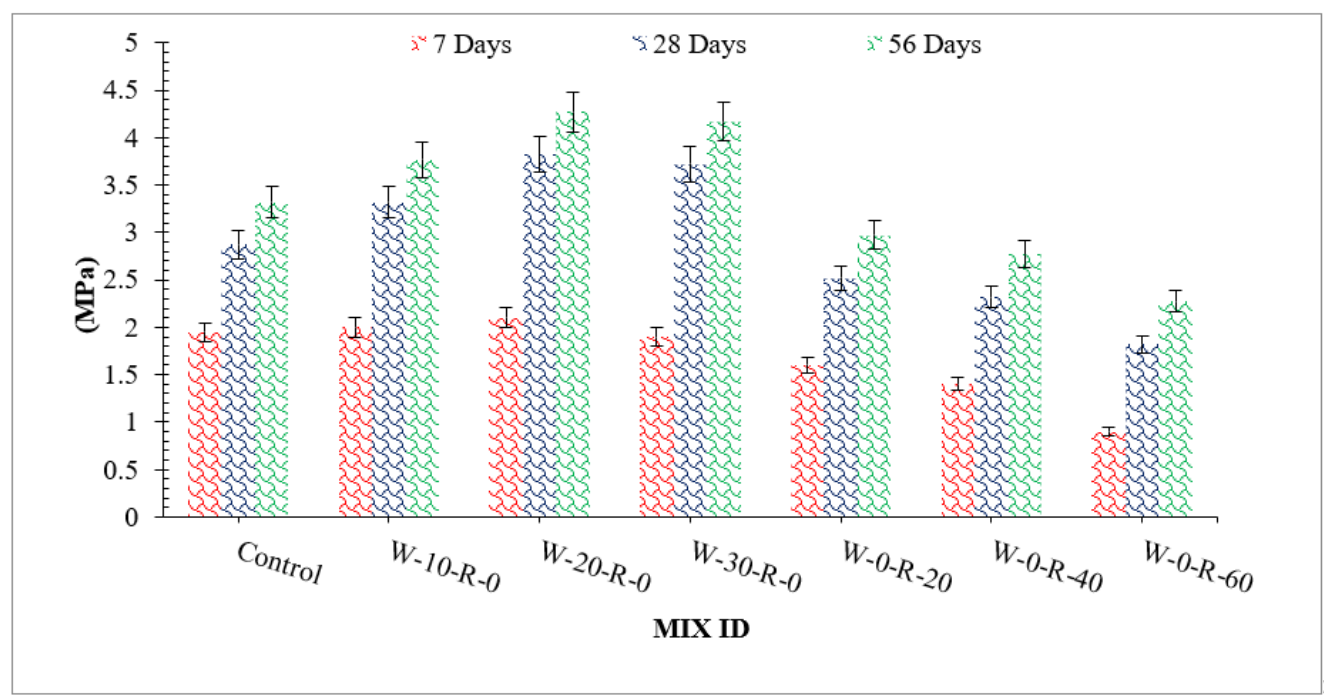

Figure 9. Split tensile strength.

\subsection{Split Tensile Strength of Concrete}

Figure 9 shows the split tensile strength of concrete with different dosages of concrete, and relative analysis of split tensile strength with respect to reference concrete is shown in Figure 10. Split tensile strength is a function of compressive strength. Split tensile strength is about $10-15 \%$ of compressive strength. Similar to compressive strength, split tensile strength increased up to $20 \%$ replacement and then decreased. Additionally, a study concluded that split tensile strength of concrete is improved up to $20 \%$ substitution of waste glass and then decreases due to lack of workability [42]. At 20\% waste glass replacement, the maximum split tensile strength was achieved, which was over $48 \%$ greater than that of reference concrete after 56 days of curing. The glass had a positive impact because of a pozzolanic reaction that provided extra binding properties, resulting in denser concrete. Micro filling of waste glass resulted in denser concrete, which led to more split tensile strength. It could also be observed that waste glass improved split tensile strength more effectively than compressive strength. A study also shows that waste glass improves split tensile strength more effectively than compressive strength due to the improvement of cement paste strength [42]. It has also been reported that concrete has less split tensile strength due to lower cement paste strength [4]. Substitution with waste glass improved the split tensile strength of concrete due to the formation of secondary $\mathrm{CSH}$, which increased the binding property of cement paste. As for RCA, split tensile strength decreased with the substitution with RCA due to its rough surface texture and porous nature. Maximum split tensile strength was achieved at $0 \%$ substitution of RCA, and minimum split tensile strength was achieved at $60 \%$ substitution of RCA. That was because of RCA's physical properties, which allowed it to absorb more water, resulting in porous concrete with lower split tensile strength. A study also observed that the split tensile strength of concrete decreases with the substitution of RCA [9].

Response surface and contour plot for split tensile strength after 28 days of curing are shown in Figures 11 and 12, respectively. It can be observed from the contour plot that RCA decreased split tensile strength while WG improved split tensile strength. Contour plots were used to optimize WG and RCA for split tensile strength. It can be observed that concrete made with $20 \%$ WG and 30\% RCA showed split tensile strength (3.0 MPa) that was approximately equal to the split tensile strength of control $(2.87 \mathrm{MPa})$. Similar doses of ( $20 \%$ WG and $40 \%$ RCA) were also cast and tested in the laboratory after 28 days of curing. It could be observed that experimental and predicted split tensile strength from the contour plot were approximately equal, which validated the predicted split tensile strength. 


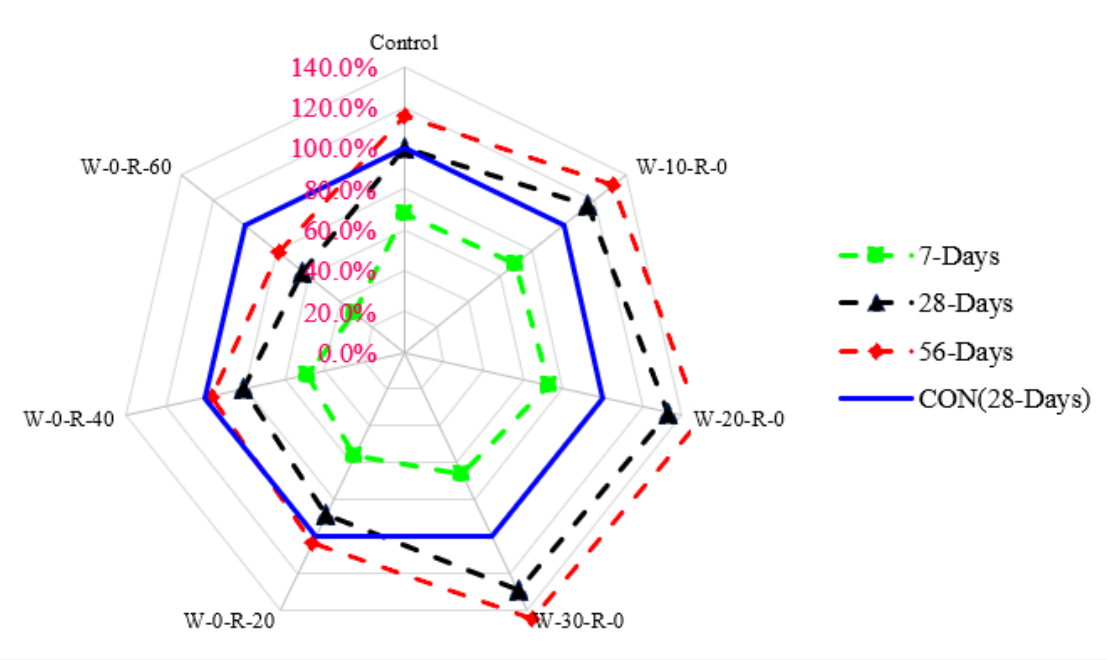

Figure 10. Relative split tensile strength.

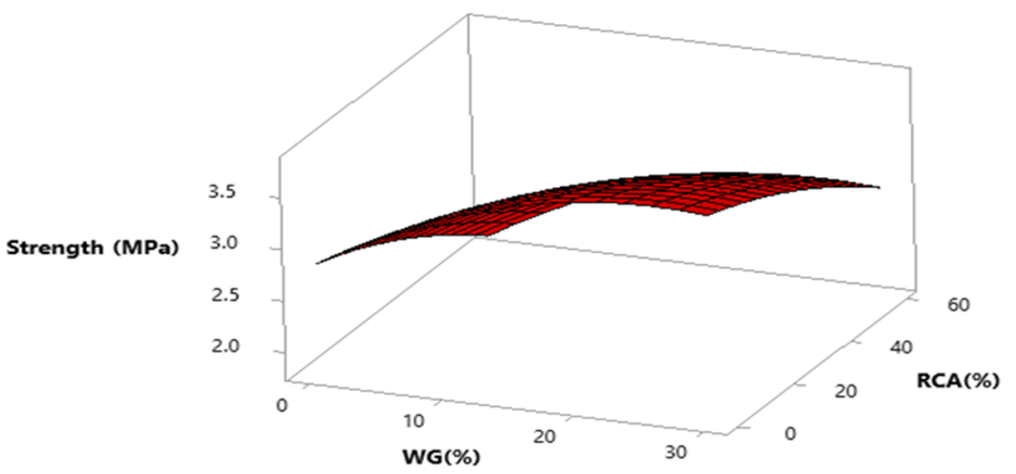

Figure 11. Three-dimensional response surface of split tensile strength.

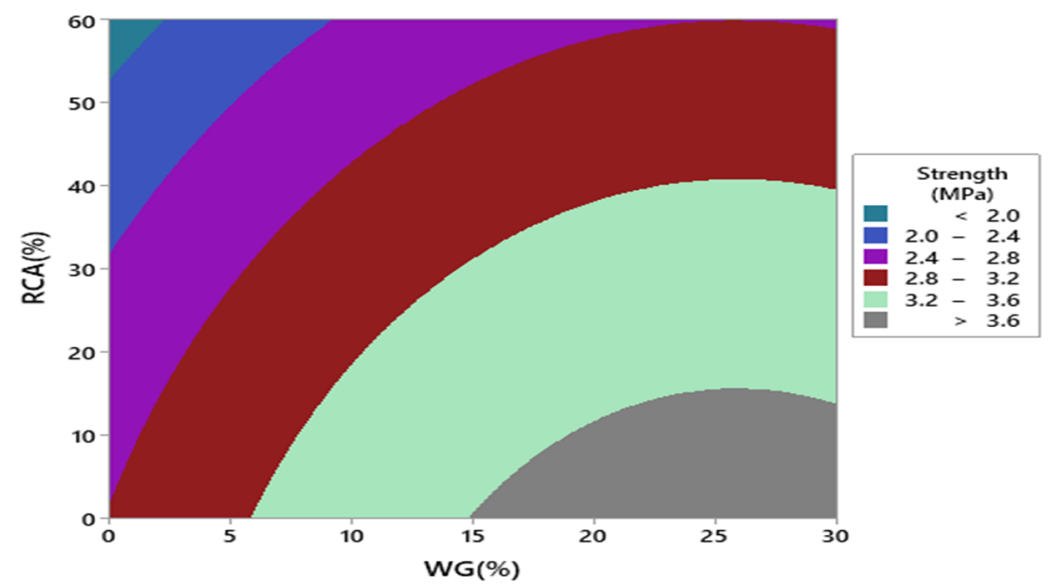

Figure 12. Contour plot of split tensile strength.

The correlation between compressive strength and split tensile strength with varying doses of waste glass and RCA at different days of curing is shown in Figure 13. A strong correlation existed between compressive strength and split tensile strength with an $\mathrm{R}^{2}$ value greater than $90 \%$. 


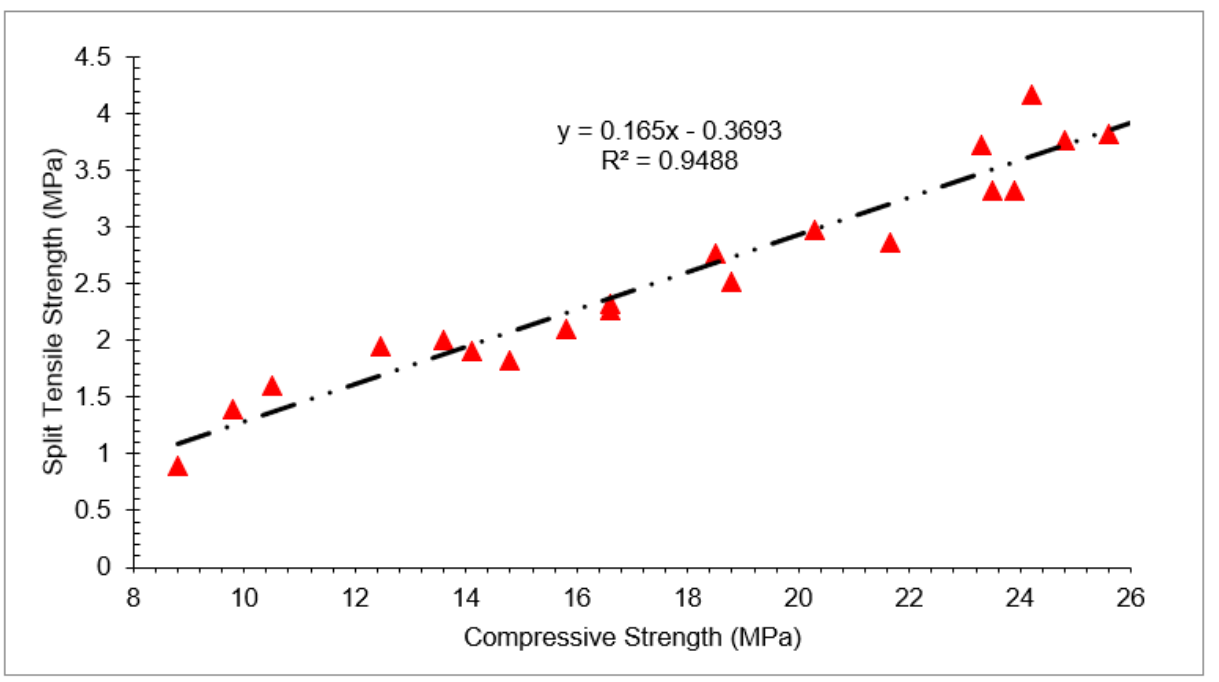

Figure 13. Correlation between compressive and split tensile strength (7, 28 and 56 days).

The following equation was developed based on experimental tests with different doses of RCA and WG.

$$
\mathrm{f}_{\mathrm{sp}}=0.165 \times \mathrm{f}_{\mathrm{c}}-0.36
$$

where

$\mathrm{f}_{\mathrm{sp}}=$ split tensile strength $\mathrm{f}_{\mathrm{c}}=$ compressive strength

Experimental split tensile strength predicted from the contour plot and predicted from Equation (3) with different doses of waste glass and RCA at 28 days of curing is shown in Table 5. Furthermore, a regression model for experimental split tensile strength, predicted from contour plot and Equation (3) with different doses of waste glass and RCA at 28 days of curing is shown in Figure 14. A strong co-relation existed among experimental split tensile strength predicted from contour plot and Equation (3), with an $R^{2}$ value greater than $90 \%$.

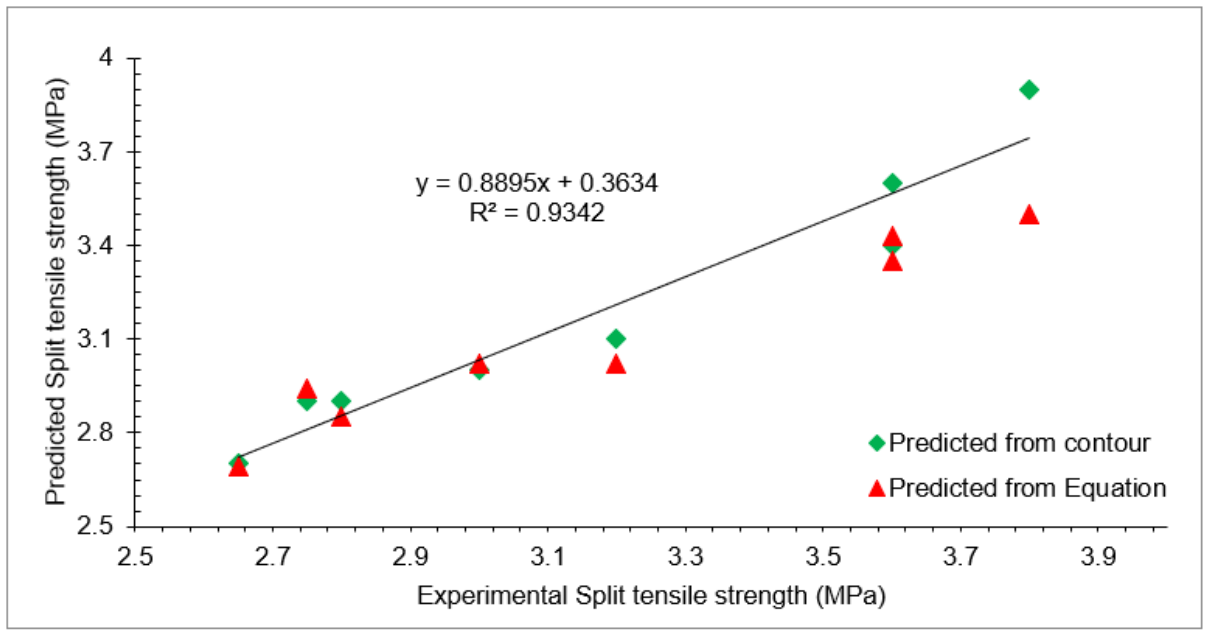

Figure 14. Correlation between experimental and predicted split tensile strength. 
Table 5. Experimental and predicted split tensile strength.

\begin{tabular}{ccccc}
\hline WG\%, RCA\% & $\begin{array}{c}\text { Compressive Strength } \\
\text { from Contour Plot }\end{array}$ & $\begin{array}{c}\text { Experimental Split } \\
\text { Tensile Strength }\end{array}$ & $\begin{array}{c}\text { Split Tensile Strength } \\
\text { from Contour Plot }\end{array}$ & $\begin{array}{c}\text { Split Tensile Strength } \\
\text { from Equation (3) }\end{array}$ \\
\hline 10,10 & 23.0 & 3.60 & 3.40 & 3.43 \\
10,20 & 20.5 & 3.20 & 3.10 & 3.02 \\
10,30 & 19.5 & 2.80 & 2.90 & 2.7 \\
10,40 & 18.5 & 2.65 & 3.9 & 3.85 \\
20,10 & 22.5 & 3.80 & 3.5 & 3.35 \\
20,20 & 21.0 & 3.60 & 3.0 & 3.02 \\
20,30 & 20.5 & 3.00 & 2.9 & 2.94 \\
\hline
\end{tabular}

\subsection{Stress-Strain Curve}

Figure 15 depicts the stress-strain curve of various waste glass and RCA dosages. The stress-strain curves for waste glass and RCA both have rising and falling sections, similar to those of conventional concrete. The tension required to induce the first strain of the waste glass was larger than that in reference concrete according to the test results. It was due to the pozzolanic reaction which gave the secondary cementitious compound (CSH). $\mathrm{CSH}$ increased the binding properties of cement paste, hence more stress was required to initiate strain. Additionally, the stress required to initiate the initial strain increased due to the micro filling of waste glass, which gave denser concrete. However, in the case of RCA, the stress required to initiate the initial strain was lower than that of reference concrete. It was due to the physical nature of RCA (voids), which absorbed more water from the cement paste and hence some part of cement remained unreactive and formed weak pockets. Similarly, due to the combined pozzolanic reaction and micro filling of waste glass, the ultimate stress increased with substitution of waste glass up to $20 \%$ and decreased due to the lack of workability. In the case of RCA, the ultimate stress decreased with the substitution of RCA. Although waste glass increased ultimate stress considerably, ultimate strain decreased with the substitution of waste, which resulted in more rigid concrete (brittle failure), which is not acceptable for any structural member. Therefore, it is recommended to use some tensile reinforcement (fibers) to improve the tensile capacity of concrete (ductile failure). In the descending portion of the stress-strain curve, reference concrete and concrete made with waste were approximately the same. However, in concrete made with RCA, the descending portion of the stress-strain curve was steeper.

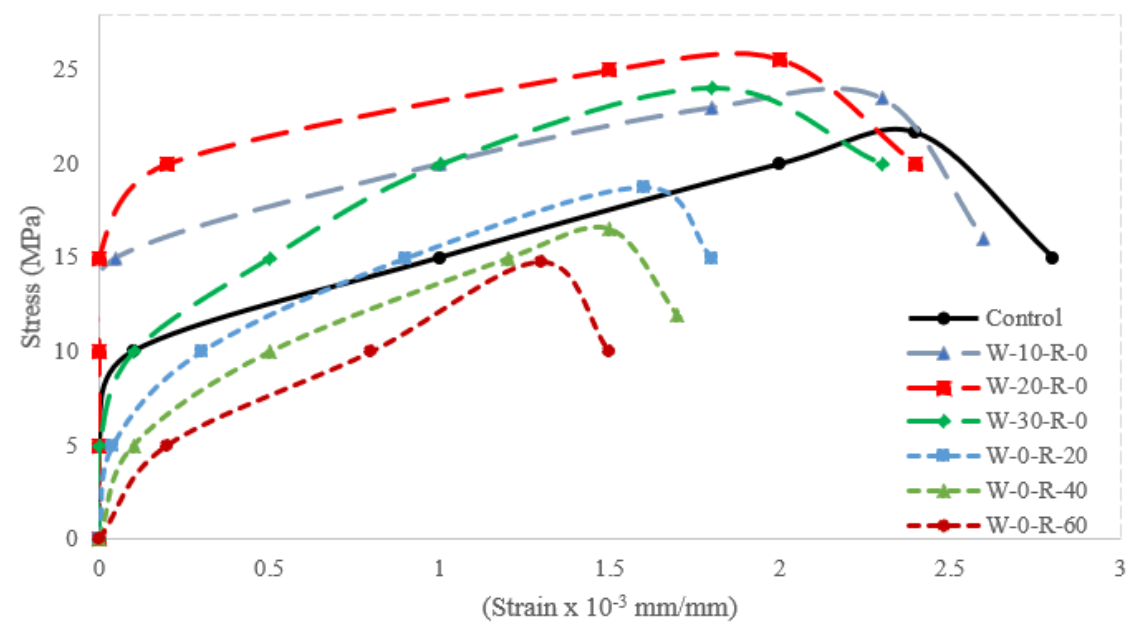

Figure 15. Stress-strain curve of various doses of waste glass and RCA. 


\subsection{Punching Strength of Concrete}

Figure 16 shows the punching strength with varying dosages of WG and RCA. Similar to compressive strength, the punching strength of concrete improved with the substitution of waste glass up $20 \%$ and then decreased due to lack of workability. Maximum punching strength was observed at $20 \%$ substitution of waste glass, and minimum punching strength was observed at $0 \%$ substitution of waste glass. The pozzolanic reaction of waste glass, which gives secondary cementitious material and micro filling, resulted in a more compact mass that positively influenced the punching strength of concrete. However, a decrease in punching strength was observed beyond $20 \%$ replacement of waste glass due to lack of workability, which resulted in more voids in hardened concrete. Additionally, a study shows that a higher dose of waste glass $(30 \%)$ results in less strength due to the dilution effect, which causes an alkali-silica reaction [42]. The amount of calcium hydrates $(\mathrm{CH})$ is consumed by a chemical reaction with silica present in waste glass, which gives secondary cementitious material (CSH gel), but at a higher dose of waste glass might be caused by an alkali-silica reaction due excessive unreactive silica. As for RCA, punching strength decreased with substitution of RCA as compared to that of control, having minimum punching strength at $60 \%$ substitution of RCA. The physical nature of RCA caused it to absorb more water, resulting in porous concrete with lower punching strength. The strength of recycled aggregate concrete has also been observed to have decreased due to unreactive cement [45]. RCA absorbs water from concrete, leaving no water for the hydration process. In addition, lack of workability tends to cause more voids in hardened concrete, leading to lower punching strength.

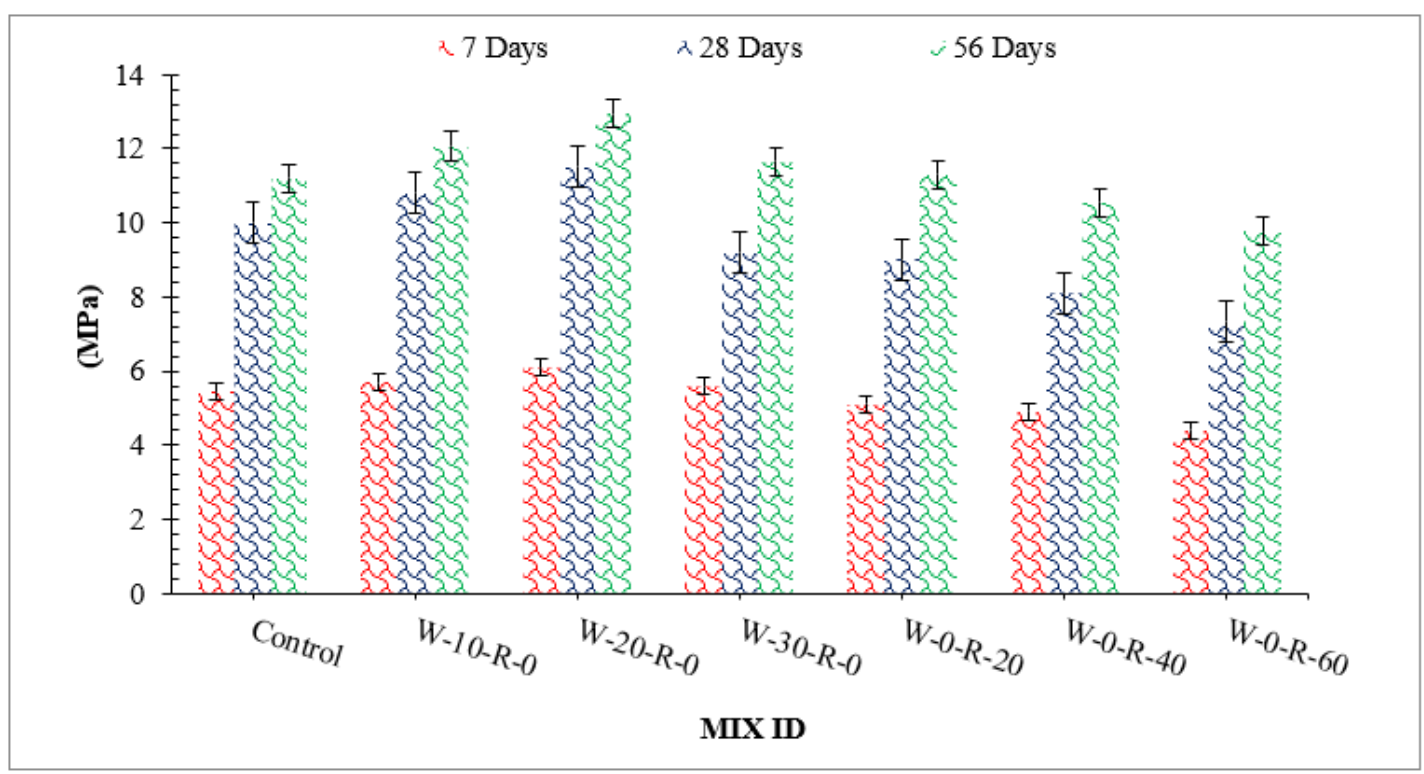

Figure 16. Punching strength.

A relative analysis of punching strength concerning 28 days of control concrete punching strength is shown $\mathrm{n}$ in Figure 17. Punching strength at 7 days of curing was $29 \%$ and $49 \%$ lower than that of reference concrete (28 days control concrete) at $20 \%$ substitution of waste glass and $30 \%$ substitution of RCA, respectively. Punching strength at $20 \%$ substitution of waste glass was $15 \%$ higher than that of reference concrete and at $20 \%$ substitution of RCA was $10 \%$ lower than that of reference concrete at 28 days of curing. Punching strength at 56 days of curing was $29 \%$ higher than that of reference concrete and at $20 \%$ substitution of RCA was approximately equal to that of reference concrete. 


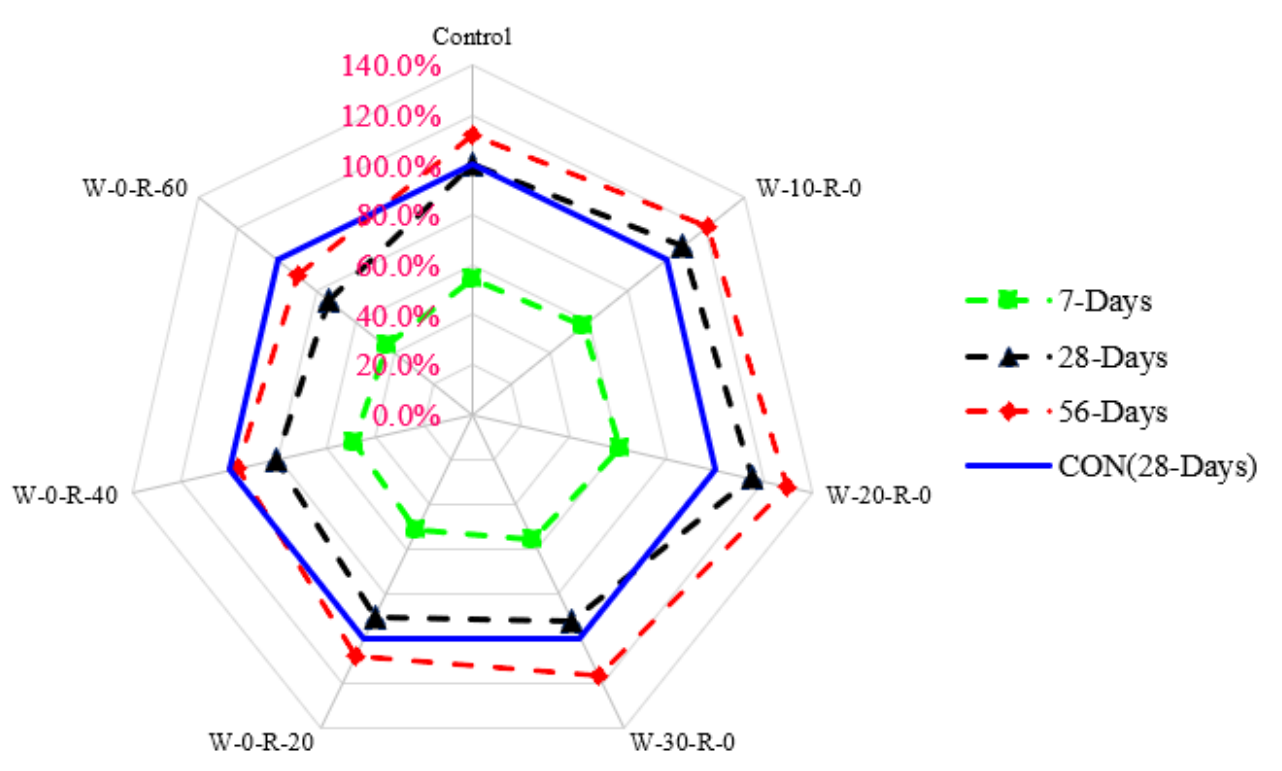

Figure 17. Relative punching strength.

Response surface and contour plot for punching strength after 28 days of curing are shown in Figures 18 and 19, respectively. It can be observed from the contour plot that RCA decreased punching strength while WG increased punching strength.

However, concrete made with 20\% WG and 40\% RCA showed punching strength (9.1 $\mathrm{MPa})$ that was approximately equal to the punching strength of control (10 $\mathrm{MPa})$, as shown in Figure 19. Similar doses (40\% RCA and 20\% WG) were also cast and tested in the laboratory. It could be observed that experimental punching strength and predicted punching strength from the contour plot were approximately equal, which validated the predicted results.

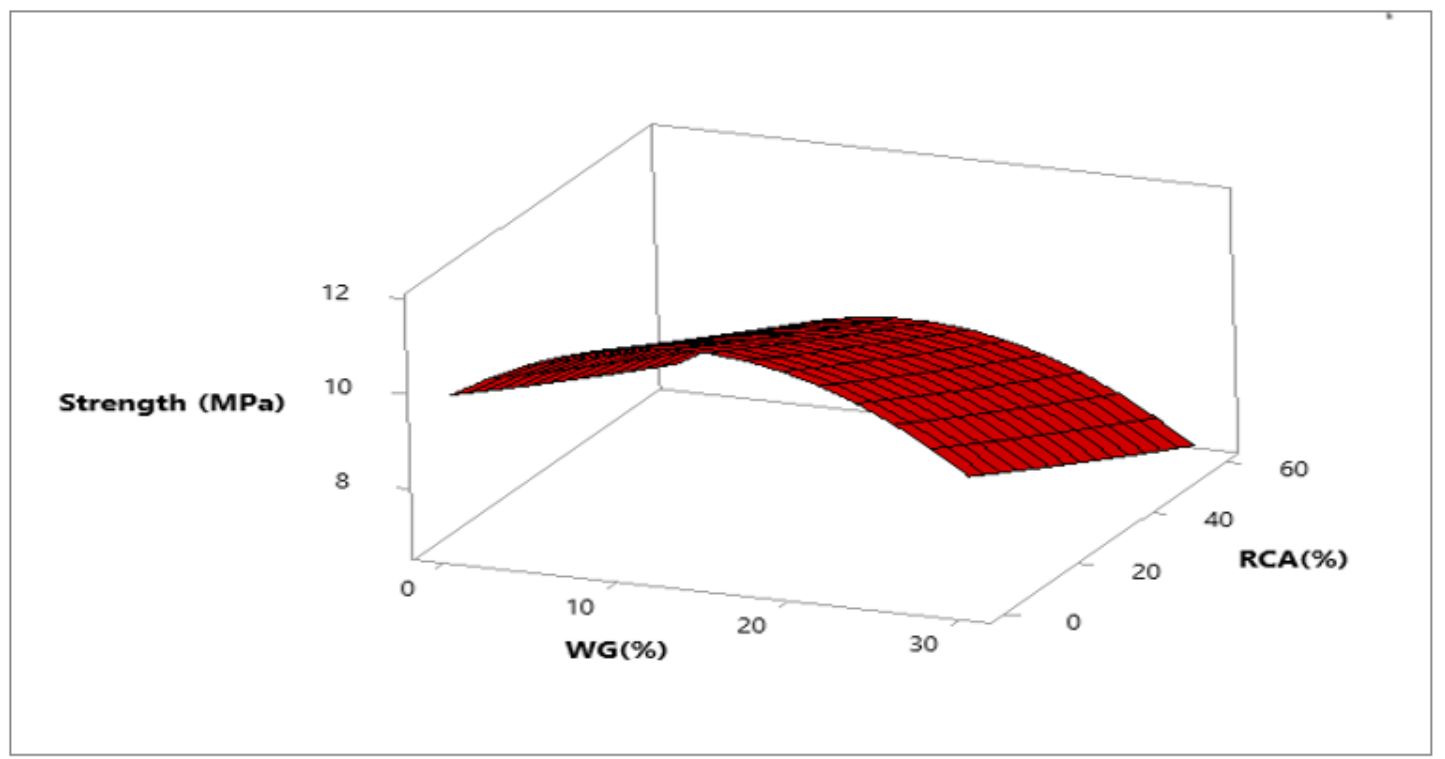

Figure 18. Three-dimensional response surface of punching strength. 


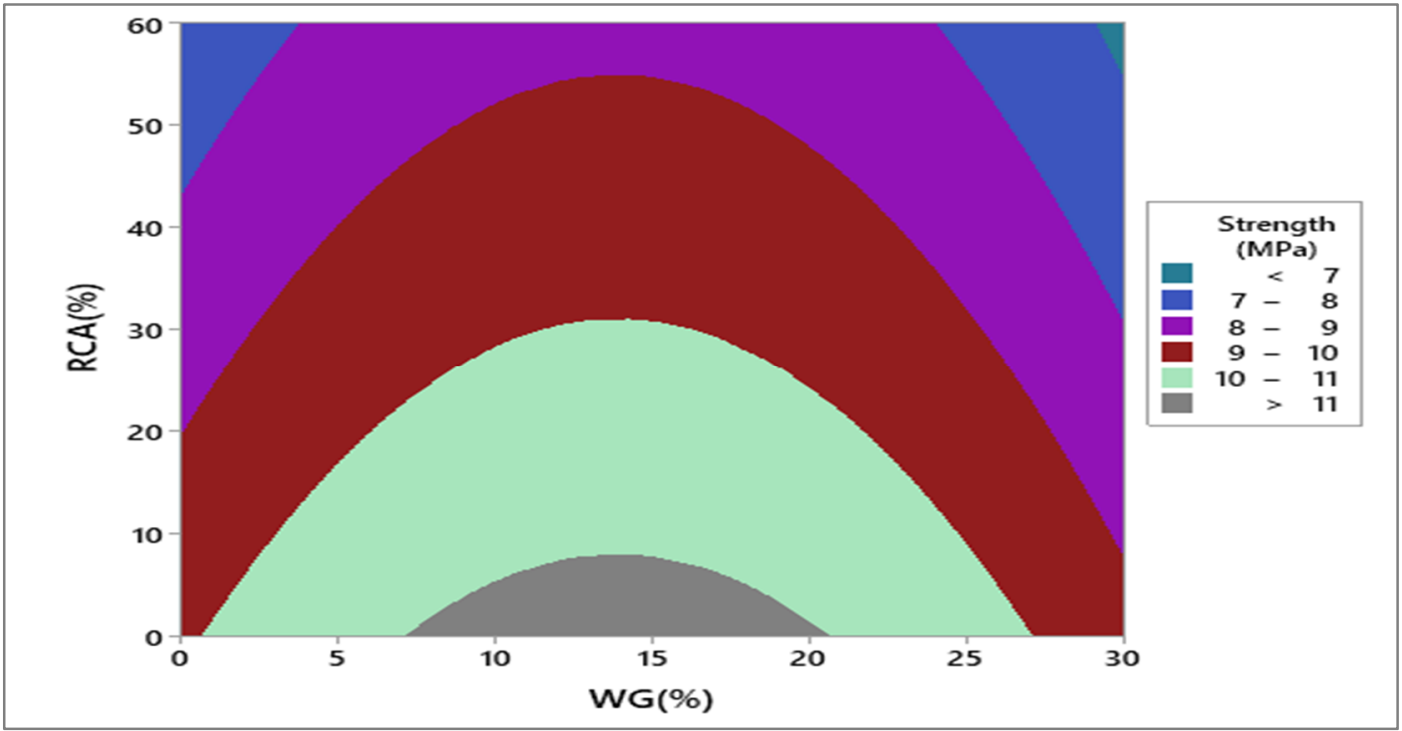

Figure 19. Contour plot for punching strength.

Correlation between compressive strength and punching strength with varying doses of waste glass and RCA at different days of curing is shown in Figure 20. A strong correlation existed between compressive strength and punching strength with an $\mathrm{R}^{2}$ value approximately equal to $90 \%(88 \%)$. The following equation was developed based on experimental tests with different doses of RCA and WG.

$$
\mathrm{f}_{\mathrm{pu}}=0.463 \times \mathrm{fc}_{\mathrm{c}}-0.207
$$

where

$$
\mathrm{f}_{\mathrm{pu}}=\text { punching strength } \mathrm{f}_{\mathrm{c}}=\text { compressive strength }
$$

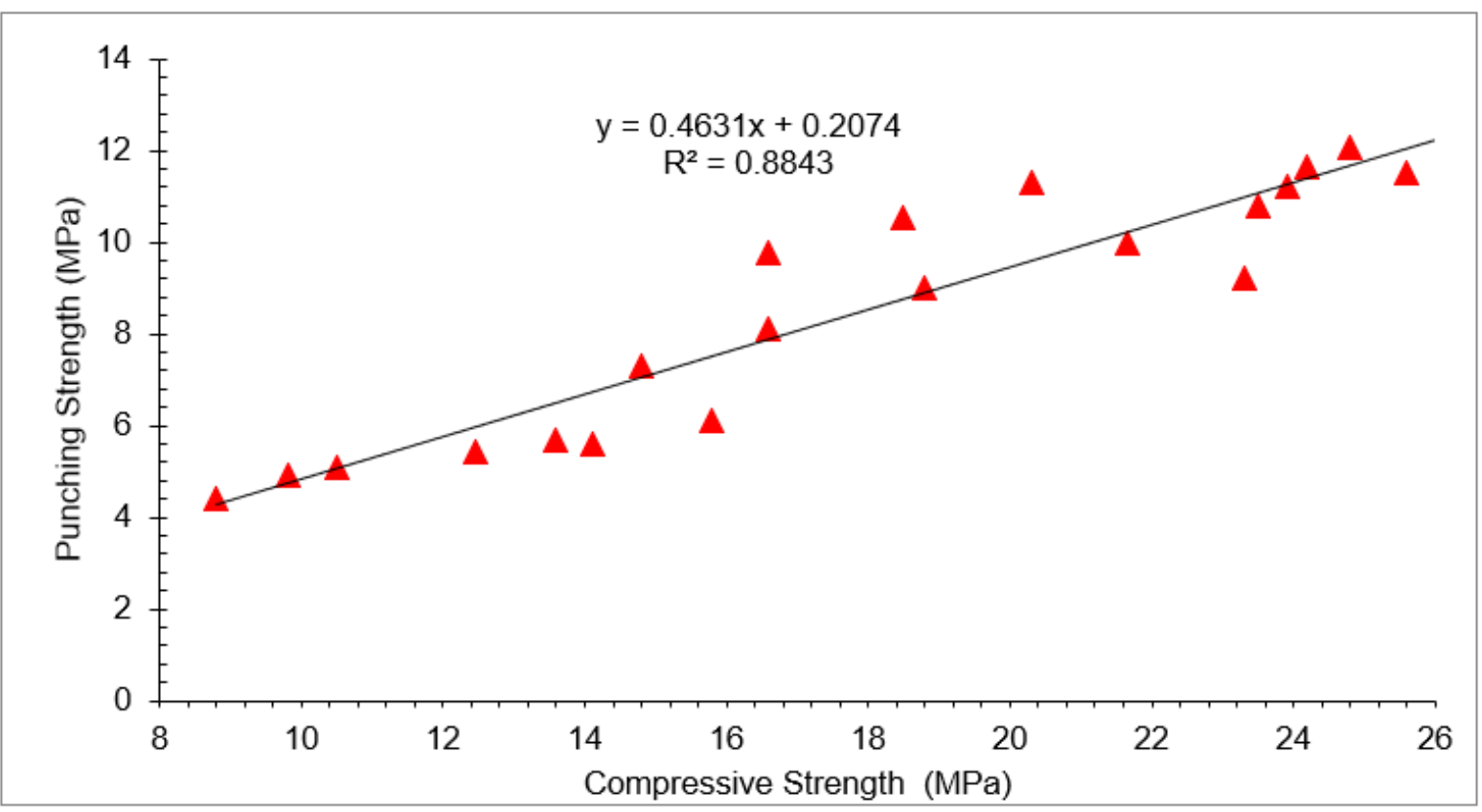

Figure 20. Correlation between compressive and punching strength (7, 28, and 56 Days).

Experimental punching strength and punching strength predicted from the contour plot and Equation (4) with different doses of waste glass and RCA at 28 days of curing are shown in Table 6. Furthermore, a regression model for experimental punching strength, 
punching strength predicted from the contour plot, and punching strength predicted from Equation (4) with different doses of waste glass and RCA at 28 days of curing is shown in Figure 21. A strong co-relation existed among experimental punching strength, punching strength predicted from the contour plot, and punching strength predicted from Equation (4), with an $R^{2}$ value approximately equal to $90 \%$.

Table 6. Experimental and predicted punching strength.

\begin{tabular}{ccccc}
\hline $\begin{array}{c}\text { WG\%, } \\
\text { RCA } \%\end{array}$ & $\begin{array}{c}\text { Compressive Strength } \\
\text { from Contour Plot }\end{array}$ & $\begin{array}{c}\text { Experimental Punching } \\
\text { Strength }\end{array}$ & $\begin{array}{c}\text { Punching } \\
\text { Strength from Contour Plot }\end{array}$ & $\begin{array}{c}\text { Experimental Punching } \\
\text { Strength from Equation (4) }\end{array}$ \\
\hline 10,10 & 23.0 & 10.24 & 10.5 & 10.44 \\
10,20 & 20.5 & 9.88 & 10.8 & 9.28 \\
10,30 & 19.5 & 9.4 & 9.8 & 8.8 \\
10,40 & 18.5 & 9.1 & 9.3 & 8.37 \\
20,10 & 22.5 & 10.3 & 10.6 & 9.21 \\
20,20 & 21.0 & 9.5 & 10.1 & 9.51 \\
20,30 & 20.5 & 9.2 & 9.7 & 9.28 \\
20,40 & 20.0 & 8.8 & 9.1 & 9.05 \\
\hline
\end{tabular}

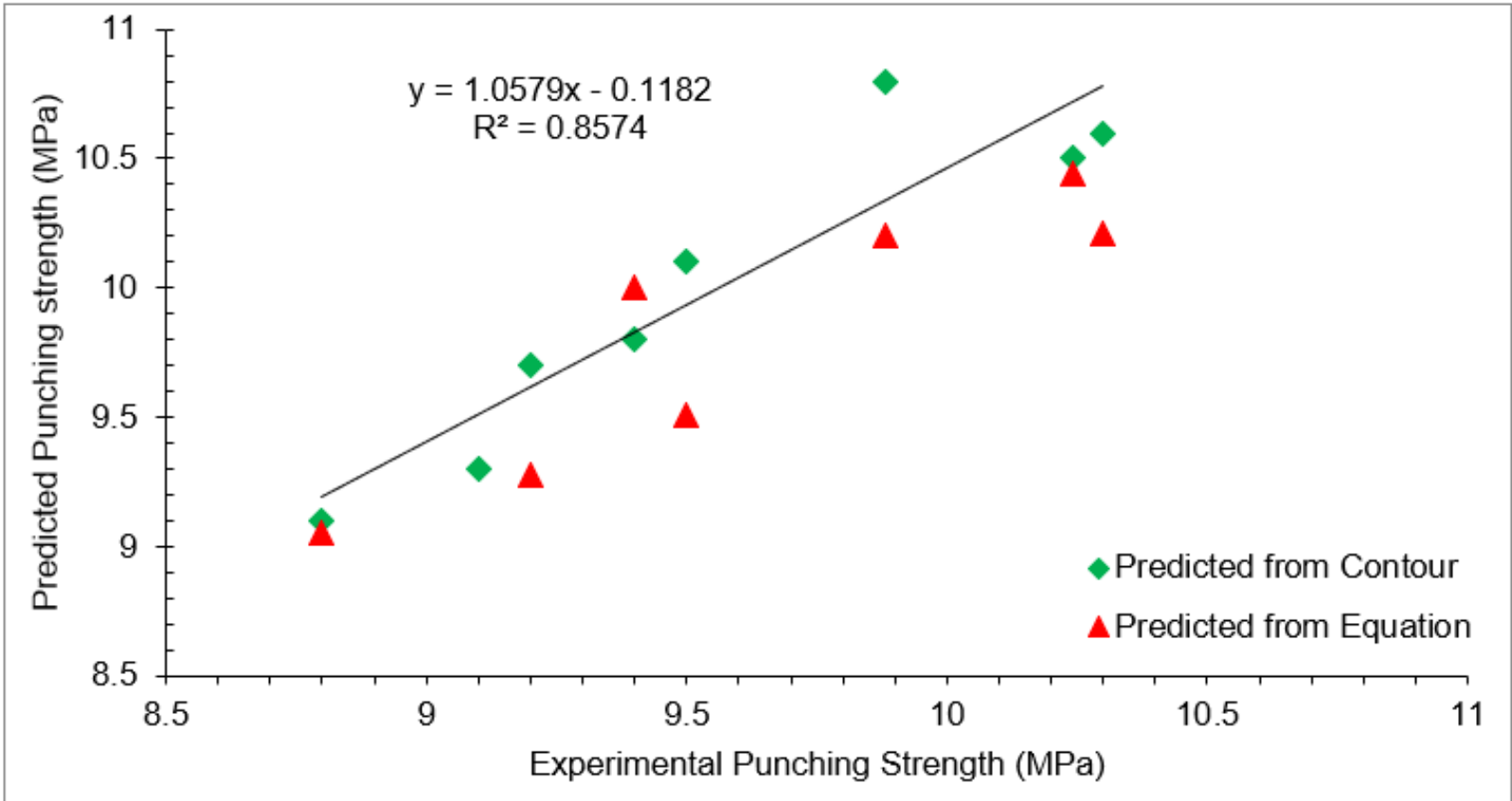

Figure 21. Correlation between experimental and predicted punching strength.

\section{Conclusions}

In this research, a step towards sustainable concrete was made by incorporating WG and RCA. The substitution ratios of WG were $0 \%, 10 \%, 20 \%$, and $30 \%$ by weight of cement, and those of RCA were $0 \%, 20 \%, 40 \%$, and $60 \%$ by weight of coarse aggregate. A detailed conclusion based on test results is given below.

- As the percentage of WG and RCA increased, the workability of concrete decreased. It was related to the physical characteristics of RCA and WG, which had a larger surface area.

- WG did not give a significant improvement in strength in the early days (seven days), as the pozzolanic reactions proceeded slowly. However, a considerable improvement in strength was observed at 28 and 56 days of curing. 
- Maximum strength was obtained at $20 \%$ substitution of WG. At 28 days of curing, compressive strength was $27 \%$ higher than that of reference concrete, while punching strength was $29 \%$ higher than that of reference concrete.

- $\quad$ RCA lowered the mechanical performance of concrete by absorbing more water from it, leaving less or no water available for hydration and workability.

- A successful statistical analysis (response surface methodology) predicted various mechanical properties and optimized WG and RCA. The optimal doses of WG and RCA ( $20 \%$ WG and 30\% RCA) were predicted from the statistical analysis, which showed compressive strength approximately equal to that of the reference concrete. Furthermore, the same doses of WG and RCA (20\% WG and 30\% RCA) were cast and tested experimentally. It could be observed that the predicted and experimental values were comparable, which validated the predicted results.

Finally, the overall study demonstrated that RCA could be successfully utilized with combined substitution of WG without any negative effect on the mechanical performance of concrete. However, it could be observed that combined substitution of WG and RCA up to some extent improved the mechanical performance of concrete. However, concrete is still weak in tension, which results in abrupt failure. Therefore, further research is recommended with addition of steel fibers or natural fibers (coconut fibers, etc.) to improve the tensile capacity of concrete.

Author Contributions: Conceptualization, J.A. and R.M.-G.; Investigation, J.A., J.d.-P.-G., K.I., M.A.E.S. and N.I.V.; Methodology, J.A., J.d.-P.-G., K.I., M.A.E.-S. and R.F.; Software, K.I.; Supervision, R.M.-G., J.d.-P.-G. and R.F.; Validation, M.A.E.-S.; Visualization, N.I.V.; Writing—original draft, J.A.; Writingreview \& editing, R.M.-G., R.F. and N.I.V. All authors have read and agreed to the published version of the manuscript.

Funding: This research is partially funded by the Ministry of Science and Higher Education of the Russian Federation under the strategic academic leadership program "Priority 2030" (Agreement 075-15-2021-1333 dated 30 September 2021).

Institutional Review Board Statement: Not applicable.

Informed Consent Statement: Not applicable.

Data Availability Statement: All Data are available in the manuscript.

Acknowledgments: Kashif Irshad acknowledges the funding support provided by the King Abdullah City for Atomic and Renewable Energy (K. A. CARE).

Conflicts of Interest: The authors declare no conflict of interest.

\section{References}

1. Mehta, P.K. Advancements in concrete technology. Concr. Int. 1999, 21, 69-76.

2. Mehta, P.K. Reducing the environmental impact of concrete. Concr. Int. 2001, 23, 61-66.

3. Mehta, P.K.; Burrows, R.W. Building durable structures in the 21st century. Concr. Int. 2001, 23, 57-63.

4. Ahmad, J.; Tufail, R.F.; Aslam, F.; Mosavi, A.; Alyousef, R.; Faisal Javed, M.; Zaid, O.; Khan Niazi, M.S. A Step towards Sustainable Self-Compacting Concrete by Using Partial Substitution of Wheat Straw Ash and Bentonite Clay Instead of Cement. Sustainability 2021, 13, 824. [CrossRef]

5. Alvee, A.R.; Malinda, R.; Akbar, A.M.; Ashar, R.D.; Rahmawati, C.; Alomayri, T.; Raza, A.; Shaikh, F.U.A. Experimental study of the mechanical properties and microstructure of geopolymer paste containing nano-silica from agricultural waste and crystalline admixtures. Case Stud. Constr. Mater. 2022, 16, e00792. [CrossRef]

6. Rahmawati, C.; Aprilia, S.; Saidi, T.; Aulia, T.B.; Hadi, A.E. The Effects of Nanosilica on Mechanical Properties and Fracture Toughness of Geopolymer Cement. Polymers 2021, 13, 2178. [CrossRef] [PubMed]

7. Rahmawati, C.; Aprilia, S.; Saidi, T.; Aulia, T.B.; Ahmad, I. Preparation and Characterization of Cellulose Nanocrystals from Typha sp. as a Reinforcing Agent. J. Nat. Fibers 2021, 1-14. [CrossRef]

8. Berndt, M.L. Properties of sustainable concrete containing fly ash, slag and recycled concrete aggregate. Constr. Build. Mater. 2009, 23, 2606-2613. [CrossRef]

9. Fediuk, R.S.; Lesovik, V.S.; Mochalov, A.V.; Otsokov, K.A.; Lashina, I.V.; Timokhin, R.A. Composite binders for concrete of protective structures. Инженерно-Строительный журнал 2018, 6, 208-218. 
10. Lee, Y.H.; Chua, N.; Amran, M.; Yong Lee, Y.; Hong Kueh, A.B.; Fediuk, R.; Vatin, N.; Vasilev, Y. Thermal Performance of Structural Lightweight Concrete Composites for Potential Energy Saving. Crystals 2021, 11, 461. [CrossRef]

11. Xie, J.; Guo, Y.; Liu, L.; Xie, Z. Compressive and flexural behaviours of a new steel-fibre-reinforced recycled aggregate concrete with crumb rubber. Constr. Build. Mater. 2015, 79, 263-272. [CrossRef]

12. Fediuk, R. Reducing permeability of fiber concrete using composite binders. Spec. Top. Rev. Porous Media An Int. J. 2018, 9, 79-89. [CrossRef]

13. Bouaissi, A.; Li, L.Y.; Abdullah, M.M.A.B.; Ahmad, R.; Razak, R.A.; Yahya, Z. Fly Ash as a Cementitious Material for Concrete. In Sustainable Building Materials; IntechOpen: London, UK, 2020.

14. Alaloul, W.S.; Musarat, M.A.; Haruna, S.; Law, K.; Tayeh, B.A.; Rafiq, W.; Ayub, S. Mechanical Properties of Silica Fume Modified High-Volume Fly Ash Rubberized Self-Compacting Concrete. Sustainability 2021, 13, 5571. [CrossRef]

15. Barabanshchikov, Y.; Usanova, K.; Akimov, S.; Uhanov, A.; Kalachev, A. Influence of electrostatic precipitator ash "zolest-bet" and silica fume on sulfate resistance of Portland cement. Materials 2020, 13, 4917. [CrossRef]

16. Sprince, A.; Korjakins, A.; Pakrastinsh, L. Creep behaviour of concrete with glass waste microfiller. In Proceedings of the Environment Technologies Resources Proceedings of the International Scientific and Practical Conference, Rezekne, Latvia, 20-22 June 2011; Volume 2, pp. 125-131.

17. Amin, S.K.; Allam, M.E.; Garas, G.L.; Ezz, H. A study of the chemical effect of marble and granite slurry on green mortar compressive strength. Bull. Natl. Res. Cent. 2020, 44, 19. [CrossRef]

18. Mirza, J.; Riaz, M.; Naseer, A.; Rehman, F.; Khan, A.N.; Ali, Q. Pakistani bentonite in mortars and concrete as low cost construction material. Appl. Clay Sci. 2009, 45, 220-226. [CrossRef]

19. Fediuk, R.S. Mechanical activation of construction binder materials by various mills. In Proceedings of the IOP Conference Series: Materials Science and Engineering, Yurga, Russia, 26-28 November 2015; IOP Publishing: Bristol, UK, 2016 ; Volume 125, p. 12019.

20. Ahmad, J.; Martínez-García, R.; Szelag, M.; de-Prado-Gil, J.; Marzouki, R.; Alqurashi, M.; Hussein, E.E. Effects of Steel Fibers (SF) and Ground Granulated Blast Furnace Slag (GGBS) on Recycled Aggregate Concrete. Materials 2021, 14, 7497. [CrossRef]

21. Benhelal, E.; Zahedi, G.; Shamsaei, E.; Bahadori, A. Global strategies and potentials to curb CO2 emissions in cement industry. J. Clean. Prod. 2013, 51, 142-161. [CrossRef]

22. Ahmad, J.; Aslam, F.; Zaid, O.; Alyousef, R.; Alabduljabbar, H. Mechanical and durability characteristics of sustainable concrete modified with partial substitution of waste foundry sand. Struct. Concr. 2021, 22, 2775-2790.

23. Imbabi, M.S.; Carrigan, C.; McKenna, S. Trends and developments in green cement and concrete technology. Int. J. Sustain. Built Environ. 2012, 1, 194-216. [CrossRef]

24. Amran, M.; Fediuk, R.; Vatin, N.; Lee, Y.H.; Murali, G.; Ozbakkaloglu, T.; Klyuev, S.; Alabduljabber, H. Fibre-reinforced foamed concretes: A review. Materials 2020, 13, 4323. [CrossRef] [PubMed]

25. Subramani, T.; Ram, S.B.S. Experimental Study on Concrete Using Cement With Glass Powder. Dep. Civ. Eng. VMKV Engg. Coll. Vinayaka Mission. Univ. Salem, India 2015, 5, 43-53.

26. Tamanna, N.; Sutan, N.M.; Tuladhar, R.; Lee, D.T.C.; Yakub, I. Pozzolanic properties of glass powder in cement paste. J. Civ. Eng. Sci. Technol. 2016, 7, 75-81. [CrossRef]

27. Lesovik, V.S.; Zagorodnyuk, L.K.; Babaev, Z.K.; Dzhumaniyazov, Z.B. Analysis of the Causes of Brickwork Efflorescence in the Aral Sea Region. Glas. Ceram. 2020, 77, 277-279. [CrossRef]

28. Talsania, S.; Pitroda, J.; Vyas, C. Experimental investigation for partial replacement of cement with waste glass powder on pervious concrete. In International Conference on: Engineering: Issues, opportunities and Challenges for Development; United Nations Educational, Scientific and Cultural Organization: Paris, France, 2015.

29. Atoyebi, O.D.; Odeyemi, S.O.; Bello, S.A.; Ogbeifun, C.O. Splitting tensile strength assessment of lightweight foamed concrete reinforced with waste tyre steel fibres. Int. J. Civ. Eng. Technol. 2018, 9, 1129-1137.

30. Gautam, S.P.; Srivastava, V.; Agarwal, V.C. Use of glass wastes as fine aggregate in Concrete. J. Acad. Indus. Res. 2012, 1, 320-322.

31. Turgut, P.; Yahlizade, E.S. Research into concrete blocks with waste glass. Int. J. Civ. Environ. Eng. 2009, 1, $203-209$.

32. Chernysheva, N.; Lesovik, V.; Fediuk, R.; Vatin, N. Improvement of Performances of the Gypsum-Cement Fiber Reinforced Composite (GCFRC). Materials 2020, 13, 3847. [CrossRef]

33. Dahmoune, F.; Remini, H.; Dairi, S.; Aoun, O.; Moussi, K.; Bouaoudia-Madi, N.; Adjeroud, N.; Kadri, N.; Lefsih, K.; Boughani, L. Ultrasound assisted extraction of phenolic compounds from P. lentiscus L. leaves: Comparative study of artificial neural network (ANN) versus degree of experiment for prediction ability of phenolic compounds recovery. Ind. Crops Prod. 2015, 77, 251-261. [CrossRef]

34. Ahmad, J.; Zaid, O.; Siddique, M.S.; Aslam, F.; Alabduljabbar, H.; Khedher, K.M. Mechanical and durability characteristics of sustainable coconut fibers reinforced concrete with incorporation of marble powder. Mater. Res. Express 2021, 8, 075505. [CrossRef]

35. Elistratkin, M.Y.; Lesovik, V.S.; Zagorodnjuk, L.H.; Pospelova, E.A.; Shatalova, S.V. New point of view on materials development. In Proceedings of the IOP Conference Series: Materials Science and Engineering, Nizhni Novgorod, Russia, $18-19$ April 2018.

36. Ahmad, J.; Zaid, O.; Aslam, F.; Shahzaib, M.; Ullah, R.; Alabduljabbar, H.; Khedher, K.M. A Study on the Mechanical Characteristics of Glass and Nylon Fiber Reinforced Peach Shell Lightweight Concrete. Materials 2021, 14, 4488. [CrossRef] [PubMed]

37. Balaguru, P.; Ramakrishnan, V. Comparison of slump cone and VB tests as measures of workability for fiber-reinforced and plain concrete. Cem. Concr. Aggreg. 1987, 9, 3-11. 
38. C39/C39M, A. Standard test method for compressive strength of cylindrical concrete specimens. Annu. B. ASTM Stand. 2003. Available online: https:/ / pdfcoffee.com/astm-c39-c39m-standard-test-method-for-compressive-strength-of-cylindricalconcrete-specimenspdf-pdf-free.html (accessed on 16 December 2021). [CrossRef]

39. Designation, A.; C496-71. Stand. Method Test Split. Tensile Strength Cylind. Concr. Specimens 1976. Available online: https: //www.astm.org/c0039_c0039m-21.html (accessed on 16 December 2021).

40. Specimen, C.T. ASTM C 31; One Set of Four Standard Cylinders for each Compressive-Strength Test, Unless Otherwise Directed. Mold Store Cylind. Lab. Test Specimens Except When Field-Cured Test Specimens Are Required. Available online: https://www.astm. org/c0031_c0031m-21a.html (accessed on 16 December 2021). [CrossRef]

41. Ahmad, J.; Manan, A.; Ali, A.; Khan, M.W.; Asim, M.; Zaid, O. A Study on Mechanical and Durability Aspects of Concrete Modified with Steel Fibers (SFs). Civil Eng. Archit. 2020, 8, 814-823. [CrossRef]

42. Ahmad, J.; Aslam, F.; Martinez-Garcia, R.; de-Prado-Gil, J.; Qaidi, S.; Brahmia, A. Effects of waste glass and waste marble on mechanical and durability performance of concrete. Sci. Rep. 2021, 11, 21525. [CrossRef]

43. Rahma, A.; El Naber, N.; Issa Ismail, S. Effect of glass powder on the compression strength and the workability of concrete. Cogent Eng. 2017, 4, 1373415. [CrossRef]

44. Ahmad, J.; Zaid, O.; Shahzaib, M.; Abdullah, M.U.; Ullah, A.; Ullah, R. Mechanical properties of sustainable concrete modified by adding marble slurry as cement substitution. AIMS Mater. Sci. 2021, 8, 343-358. [CrossRef]

45. Zaid, O.; Ahmad, J.; Siddique, M.S.; Aslam, F.; Alabduljabbar, H.; Khedher, K.M. A step towards sustainable glass fiber reinforced concrete utilizing silica fume and waste coconut shell aggregate. Sci. Rep. 2021, 11, 12822. [CrossRef] [PubMed] 